Portland State University

PDXScholar

TREC Final Reports

Transportation Research and Education Center

(TREC)

6-2014

\title{
Effect of Light-Rail Transit on Traffic in a Travel Corridor
}

\author{
Reid Ewing \\ University of Utah \\ Guang Tian \\ University of Utah \\ Allison Spain \\ University of Utah
}

Follow this and additional works at: https://pdxscholar.library.pdx.edu/trec_reports

Part of the Transportation Commons, and the Urban Studies and Planning Commons Let us know how access to this document benefits you.

\section{Recommended Citation}

Ewing, R., Tian, G., Spain, A. "Effect of Light-Rail Transit on Traffic in a Travel Corridor" NITC-RR-611. Portland, OR: Transportation Research and Education Center (TREC), 2014. https://doi.org/10.15760/ trec.56

This Report is brought to you for free and open access. It has been accepted for inclusion in TREC Final Reports by an authorized administrator of PDXScholar. Please contact us if we can make this document more accessible: pdxscholar@pdx.edu. 


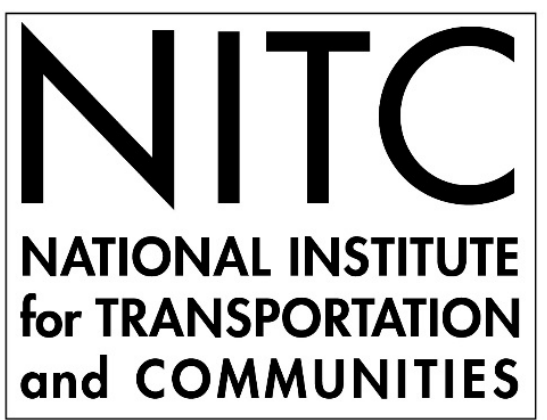

FINAL REPORT

\section{Effect of Light-Rail Transit on Traffic in a Travel Corridor}

NITC-RR-611

June 2014 



\title{
EFFECT OF LIGHT-RAIL TRANSIT ON TRAFFIC IN A TRAVEL CORRIDOR
}

\author{
Final Report
}

NITC-RR-611

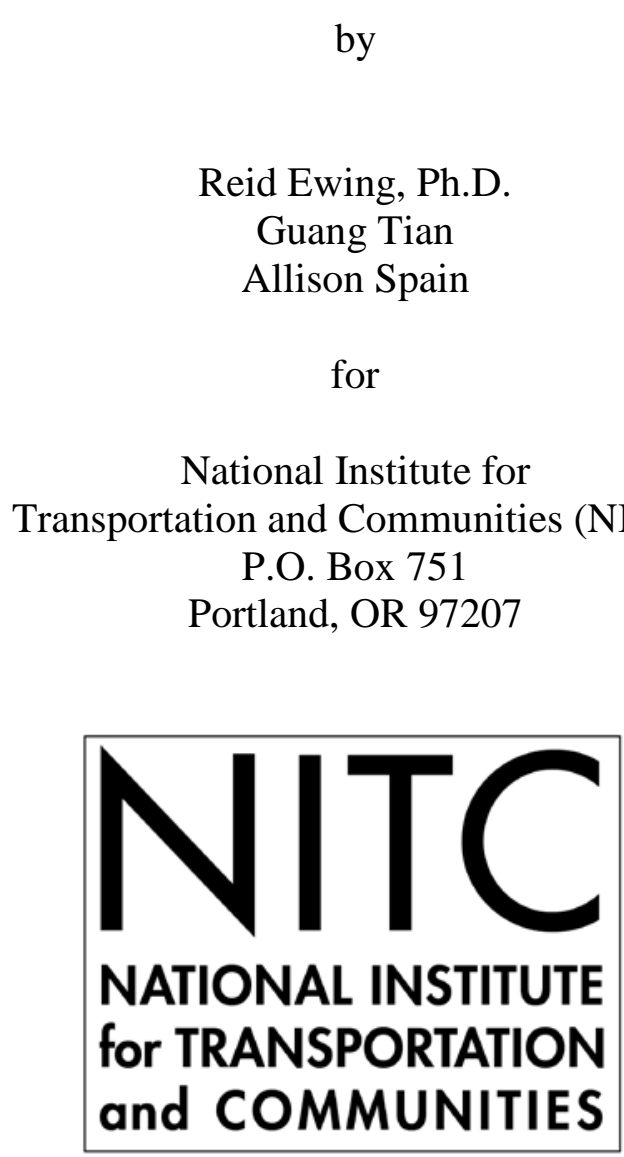

June 2014 



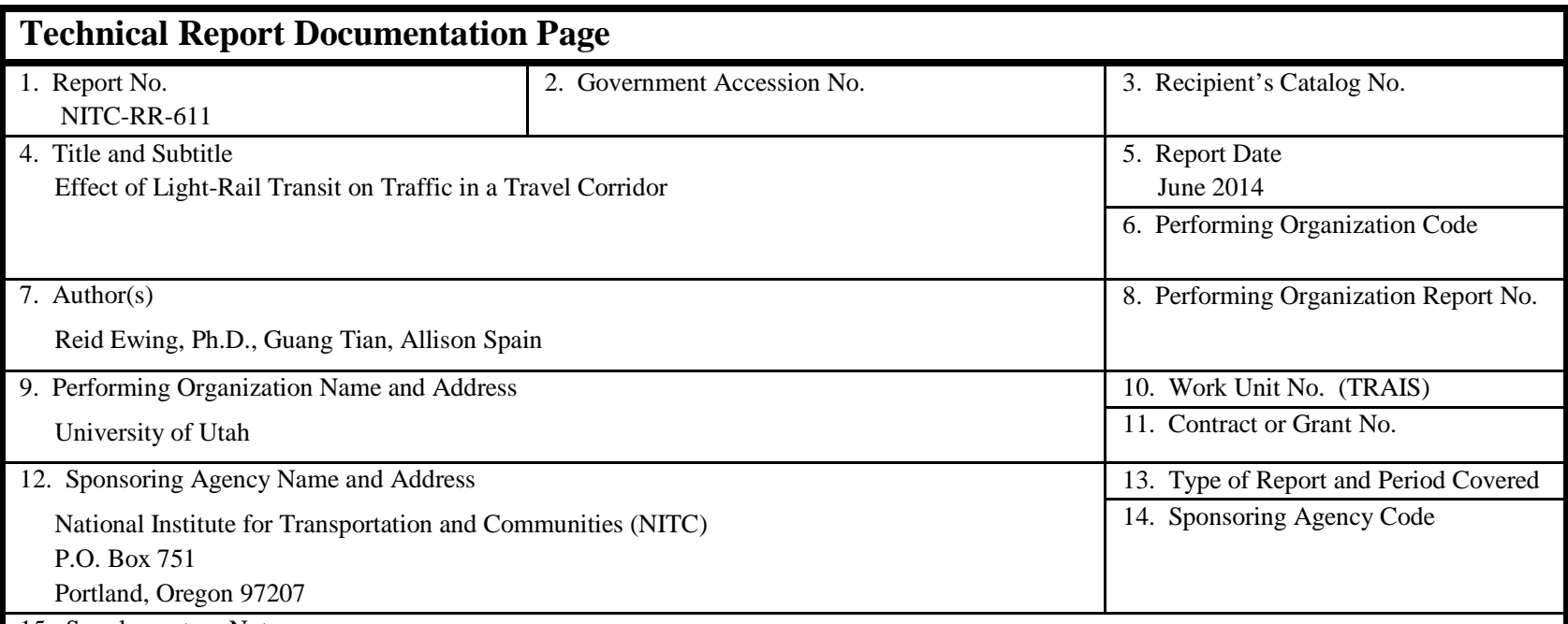

15. Supplementary Notes

16. Abstract

This study seeks to quantify the effect of the University TRAX light-rail line on traffic near the University of Utah, providing quantitative data that can be used to shape future transportation policies aimed at reducing traffic congestion, energy consumption, air pollution, greenhouse gas emissions, and parking costs. Travel demand models have long been used to estimate and evaluate the effects of transportation improvements, like LRT investments, on network travel flows and times as part of long-range planning studies, using four-step models or more sophisticated urban simulation studies. However, these are usually ex ante studies. Few ex post evaluations have been done, and in this sense, the effects of transit on traffic volumes and associated energy consumption and air pollution have not been rigorously evaluated to support or refute the justification for subsidized transit. Such quantification is required for a comprehensive cost-benefit analysis. Our aim is to provide the first hard evidence of light-rail's impact on traffic in a travel corridor, to quantify the associated savings on energy consumption, air pollution, and parking costs, and to compare cost savings to transit subsidies.

17. Key Words

18. Distribution Statement

No restrictions. Copies available from NITC: www.otrec.us/nitc

19. Security Classification (of this report)

20. Security Classification (of this page)
Unclassified

21. No. of Pages
37


NITC report

\section{Effects of Light-Rail Transit on Traffic in a Travel Corridor}

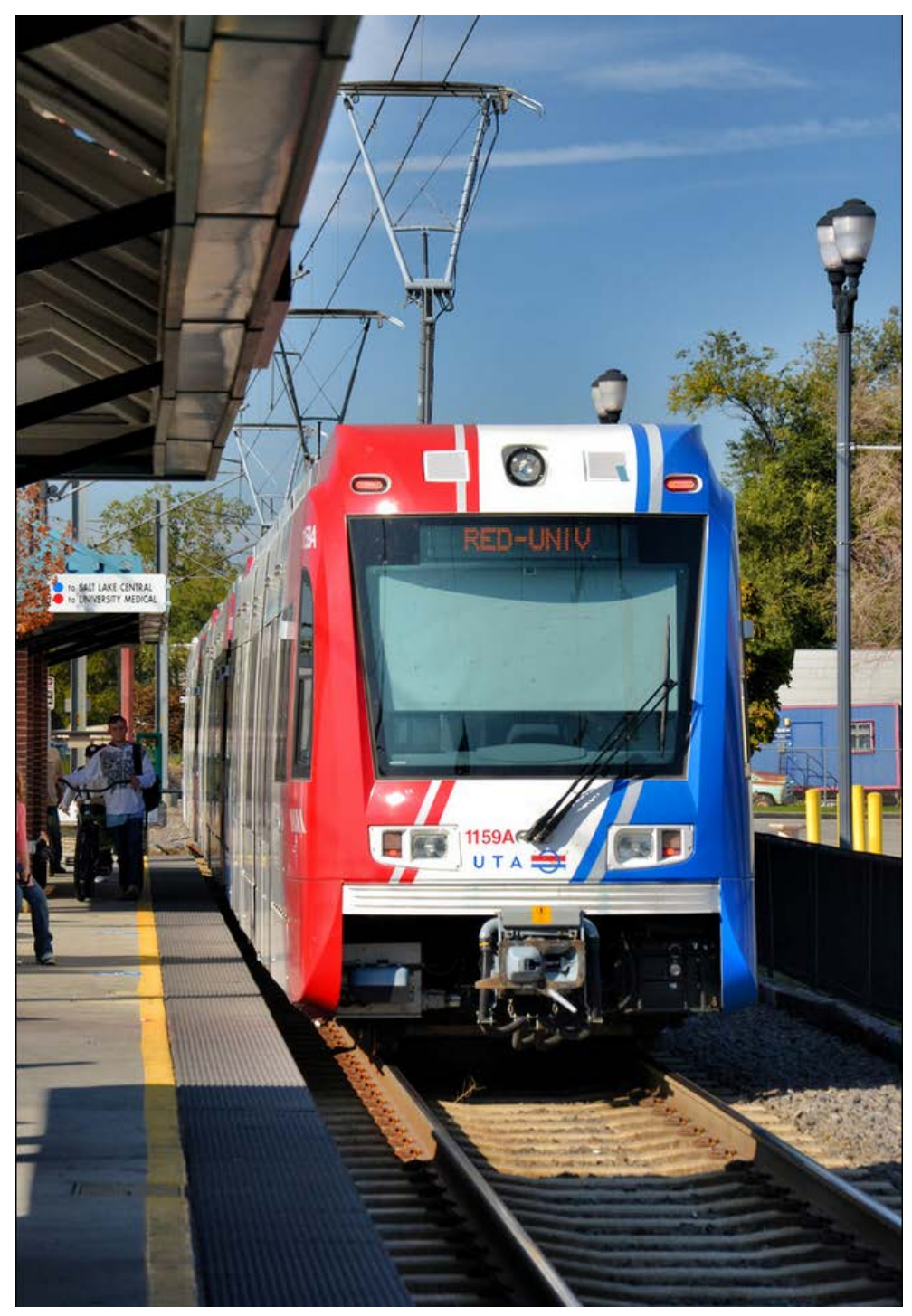

\section{Reid Ewing Guang Tian Allison Spain}

Metropolitan Research Center University of Utah 


\section{TABLE OF CONTENTS}

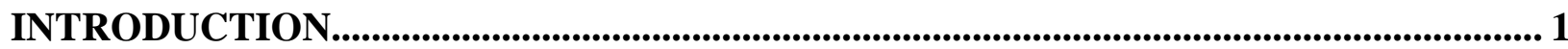

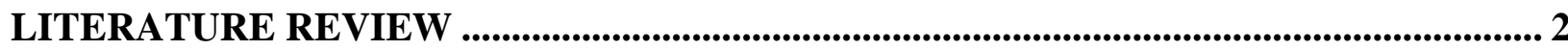

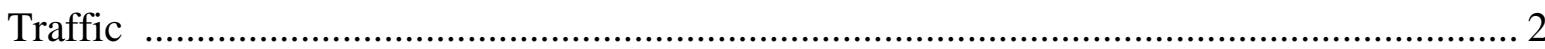

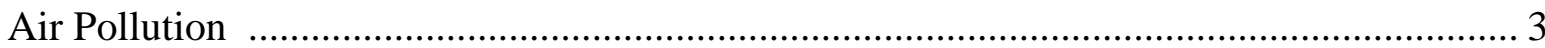

LONGITUDINAL ANALYSES AND NATURAL EXPERIMENTS....................................... 3

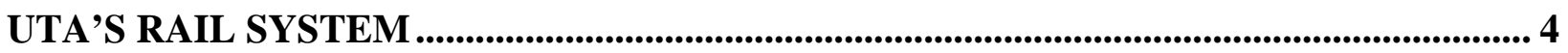

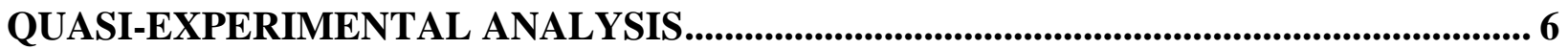

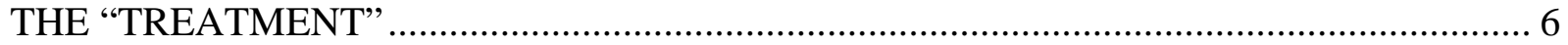

TRAFFIC COUNTS .................................................................................................. 7

SHORT-TERM IMPACT OF TRAX - PRETEST-POSTTEST WITHOUT A COMPARISON

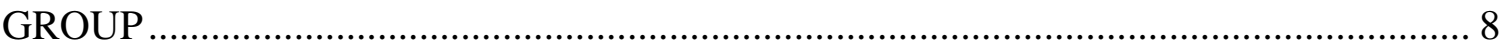

MEDIUM-TERM IMPACT OF TRAX - PRETEST-POSTTEST WITH A COMPARISON

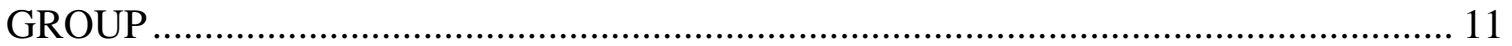

LAND-USE CHANGES............................................................................................ 13

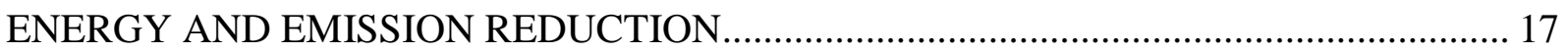

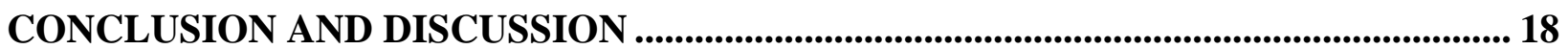

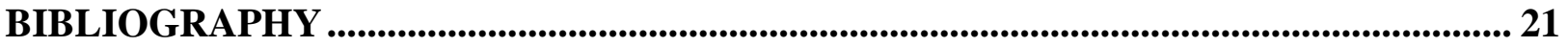

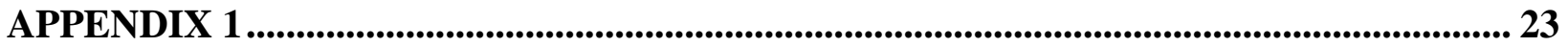

\section{LIST OF TABLES}

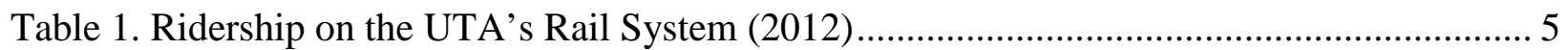

Table 2. Annual Average Daily Traffic on 400/500 South and University Line Ridership ............ 7

Table 3. Effect of TRAX on Traffic on 400/500 South ............................................................... 9

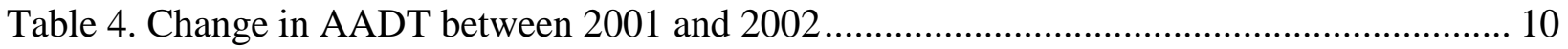

Table 5. Bus Ridership on 400/500 South .................................................................................. 11

Table 6. Changes of Building Floor Area by Land-Use Type between 1999 and 2009 for Parcels that Changed ...................................................................................................... 14

Table 7. Total Building Floor Area in the 400/500 South Corridor by Land-Use Type .............. 15

Table 8. Total Trip Generation by Land-Use............................................................................. 15

Table 9. Estimates of Traffic Reduction on 400/500 South Due to TRAX................................. 17

Table 10. EPA Average Emissions and Fuel Consumption for Passenger Cars .......................... 17

Table 11. Effect of TRAX on Energy Consumption and Emission Reduction ............................. 18 


\section{LIST OF FIGURES}

Figure 1. UTA Rail Systems Map................................................................................... 5

Figure 2. Timeline of the University TRAX Line ...................................................................... 6

Figure 3. Average Daily Traffic on 400/500 South, TRAX Ridership along 400/500 South, and Bus Ridership along 400/500 South........................................................................ 9

Figure 4. AADT on Streets Parallel to TRAX ……………......................................................... 10

Figure 5. 400/500 South and Comparison Roads (700 East and 1300 East) .................................. 12

Figure 6. Average AADT on 700 East and 1300 East ................................................................. 13

Figure 7. Parcels that Changed between 1999 and 2009 (highlighted in yellow) ........................ 14

Figure 8. Local AADT on 400/500, Estimated Local Traffic on 400/500 Based on the Trip

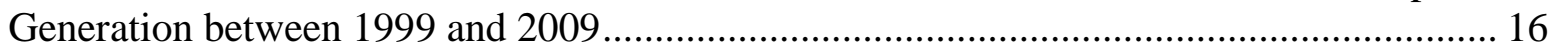




\section{Effects of Light-Rail Transit on Traffic in a Travel Corridor}

Reid Ewing, Guang Tian and Allison Spain

Metropolitan Research Center

University of Utah

\section{Introduction}

This study seeks to quantify the effect of the University TRAX light-rail line on traffic near the University of Utah, providing quantitative data that can be used to shape future transportation policies aimed at reducing traffic congestion, energy consumption, air pollution, greenhouse gas emissions, and parking costs. Initial studies conducted by the Utah Transit Authority (UTA) on data collected by the Utah Department of Transportation showed that traffic near the university has fallen to levels not seen since the 1980s, even as the number of students, faculty and staff at the university has increased. What is less clear is exactly why this occurred. The university is the second-largest traffic generator in the state, and concerted efforts to encourage commuters to use transit to and from the university have resulted in a large number of commuters adopting transit as a primary means of commuting. A survey conducted in 2005 found that nearly a quarter of students, faculty and staff at the university used transit as a primary mode of transportation to and from campus.

An audit ordered by the Utah State Legislature in 2008 found that transit passes issued to students, faculty and staff at educational institutions recovered just 8 percent of the cost of service. By comparison, other types of passes recovered an average of 24 percent of the cost of service. Determining the effect of the TRAX light-rail lines serving the University of Utah campus on traffic along parallel arterial streets will make it possible to quantify the savings in traffic congestion, energy consumption, air pollution and parking costs such subsidies provide, and allow a full evaluation of the partnership between the university and the UTA.

Travel demand models have long been used to estimate and evaluate the effects of transportation improvements, like LRT investments, on network travel flows and times as part of long-range planning studies, using four-step models or more sophisticated urban simulation studies. However, these are usually ex ante studies. Few ex post evaluations have been done, and in this sense, the effects of transit on traffic volumes and associated energy consumption and air pollution have not been rigorously evaluated to support, or refute the justification for subsidized transit. Such quantification is required for a comprehensive cost-benefit analysis. Transit is assumed to reduce traffic congestion, and alleviate the negative impacts of congestion. The introduction of TRAX light-rail service to the university provides a quasi-experiment from which we can quantify the before-and-after impacts of transit. Our aim is to provide the first hard evidence of light-rail's impact on traffic in a travel corridor, to quantify the associated savings on energy consumption, air pollution, and parking costs, and to compare cost savings to transit subsidies. 


\section{Literature Review}

Many regions around the United States are developing LRT systems as an alternative to the automobile. LRT has become an attractive option because of its ability to be located in a variety of land use contexts, from suburbs to high-density central business districts. Living near LRT stations offers an array of benefits that have been measured through several studies. These benefits arise from lower transportation costs, changing development patterns, higher property values, and reducing air pollution.

\section{Traffic}

The statement "you can't pave your way out of congestion" is generally accepted. Litman (2010) identifies errors in the arguments for highway expansion to reduce traffic congestion. As an alternative, LRT has the potential to reduce regional traffic congestion because it does not (unlike highway expansion) induce additional regional vehicle miles traveled (VMT). Indeed, from recent studies, it has the opposite effect (Hyman and Mayhew 2002; Schrank, Eisele and Lomax 2012; Ewing et al. 2008; Cervero and Murakami 2010; Ewing et al. 2014).

The Texas A\&M Transportation Institute's (TTI) 2012 Urban Mobility Report reports that in the 498 urban areas studied, there were approximately 56 billion passenger miles of travel on public transportation systems in 2011. Overall, if these riders were not handled on public transportation systems they would contribute an additional roadway delay of almost 865 million hours, or about a 15 percent increase in the total delay. Of the 865 million hours of potential extra delay, 816 million were estimated to be in 101 larger urban areas, including Salt Lake City and Provo-Orem.

Regional studies also show that LRT development affects vehicular traffic congestion. Research by Winston and Langer (2006) indicates that both motorists and truck congestion costs decline in a city as rail transit mileage expands. Garrett and Castelazo (2004) found that traffic congestion growth rates declined in several U.S. cities after LRT was established. A study of traffic congestion in Denver indicated that traffic within the zone of influence of the light-rail system increased 31 percent compared with 41 percent outside the zone of influence (Bhattacharjee and Goetz 2012). A study in Baltimore showed that congestion increased an average of 2.8 percent annually before light-rail, but only 1.5 percent annually after light-rail was implemented (Litman 2012). Litman (2012) also found that cities with rail systems have significantly higher per capita transit ridership and lower per capita vehicle ownership than cities with no rail transit service. Goldstein (2007) found that households located within walking distance to rail transit stations drive 30 percent less on average than those located in less transit-accessible locations.

However, Senior (2009) and Lee et al. (2013) questioned the effect of LRT on car ownership and car use. They argued that rail ridership increases come from bus trips that are diverted to rail. They concluded that light-rail was only somewhat successful in decreasing car use for journeys to work and made at best only a minimal impact on road congestion, partly because of the lack of coordinated car restraint policies. Duranton and Turner (2011) also found no evidence that public transportation relieves road congestion. They argued that whenever a driver shifts onto public transportation, another is going to use the open lane. 


\section{Air Pollution}

TTI's 2012 Urban Mobility Report reports that 380 pounds of CO2 were emitted per auto commuter during congestion in 2011, versus 160 in 1982. The effects of transit on air pollution and greenhouse gas emissions are subject to debate. Using structural equation modeling, Ewing et al. (2008) and Bailey et al. (2008) find that transit service reduces urban VMT and associated emissions both directly through mode shifts and indirectly through land use changes. In a holistic approach measuring the impacts of transit in Washington D.C., Los Angeles, and London, Parry and Small (2009) show the benefits of subsidizing urban transit: substantial reductions in congestion, pollution, and traffic accidents.

On the other hand, O'Toole (2008) questions the supposed reduction in energy and greenhouse gas emissions from public transportation. The substantial fossil fuel consumption by public transport does not guarantee that a city will save energy or meet greenhouse gas targets by investing in public transportation. Since public transportation generally uses diesel fuels and electricity, the mix of pollutants emitted by public transportation must be considered as an offset to automobile pollution reduction.

From our literature review, we found no study that used a similar, carefully controlled research design to estimate the effects transit has on traffic, energy consumption, air pollution, and parking costs in a travel corridor.

\section{Longitudinal Analyses and Natural Experiments}

The vast majority of studies on travel and the built environment are cross sectional in nature, using travel data at a single point in time to explain travel behavior. The Transportation Research Board (TRB) report, Does the Built Environment Influence Physical Activity? Examining the Evidence, calls for longitudinal studies that use data for the same places over time to explain changes in behavior. These are rare because longitudinal data are rare. According to the TRB, “...most of the studies conducted to date have been cross sectional. Longitudinal study designs using time-series data are also needed to investigate causal relationships between the built environment and physical activity." The same need exists in studies of travel behavior.

The TRB report also calls for studies of so-called natural experiments, changes that occur naturally when some public or private action alters the built environment. If baseline data are available, the effect of the change can be quantified. "When changes are made to the built environment-whether retrofitting existing environments or constructing new developments or communities-researchers should view such natural experiments as 'demonstration' projects and analyze their impacts on physical activity." Again, the same opportunity exists when natural experiments alter travel behavior.

Such natural experiments occur every time a new transit line is built. Well-located transit lines will attract new development, changing the built environments of the station areas. We would expect to see a corresponding change in travel behavior. 


\section{UTA's Rail System}

UTA's initial LRT line (the Blue Line) was opened in 1999. It runs from downtown Salt Lake City to Sandy, a suburban community in southern Salt Lake County. In August 2000, construction began on an extension from downtown to the University of Utah's southwest corner at the Rice-Eccles stadium (the Red Line). That line was opened in December 2001. The actual ridership of the University line far exceeded projected ridership. UTA projected 4,300 riders in the opening year and ended up with 7,500.

In May 2002, work began on an extension of the University TRAX line to the University Medical Center at the Northeast corner of campus. That line was opened in September 2003. This LRT Line received a grant for $\$ 241 \mathrm{M}$ dollars. UTA contributed $\$ 71 \mathrm{M}$ in local funds. The University Line was also funded at $80 \%$ level. Total cost was $118 \mathrm{M}$. Finally, the Medical Center extension was funded at a $60 / 40$ level. Total cost was $\$ 89 \mathrm{M}$.

Since then, the UTA's LRT system (including commuter rail) has been expanded with:

August 2011 - 5.1-mile, four-station extension of the Green Line to the West Valley City Center August 2011 - 10.6-mile, nine-station extension of the Red Line to Daybreak in South Jordan April 2013 - 6-mile, six-station extension of the Green Line to the Salt Lake International Airport August 2013 - 3.5-mile, three-station extension of the Blue Line to Draper April 2008 - 44-mile, eight-station commuter rail of FrontRunner North December 2012 - 45-mile, seven-station commuter rail extension of FrontRunner South Each of these rail extensions represents a natural experiment, which can be studied for its impacts on travel within the rail corridor by comparing conditions before the extension to conditions after the extension. This study focuses on the University Extension because adequate time has passed since the extension for the full effects to be felt. The University Extension is also interesting because it has the highest ridership on the system (see Table 1). The system is free for students, as part of tuition and registration fees. Those holding tickets to all University of Utah home games can ride the TRAX for free. The University line has short headways during the peak period (15 minute headways). The university is a commuter school, and the TRAX line serves heavy traffic from the downtown hub and points south and west. There is local promotion by city government to use TRAX for air pollution reduction. 


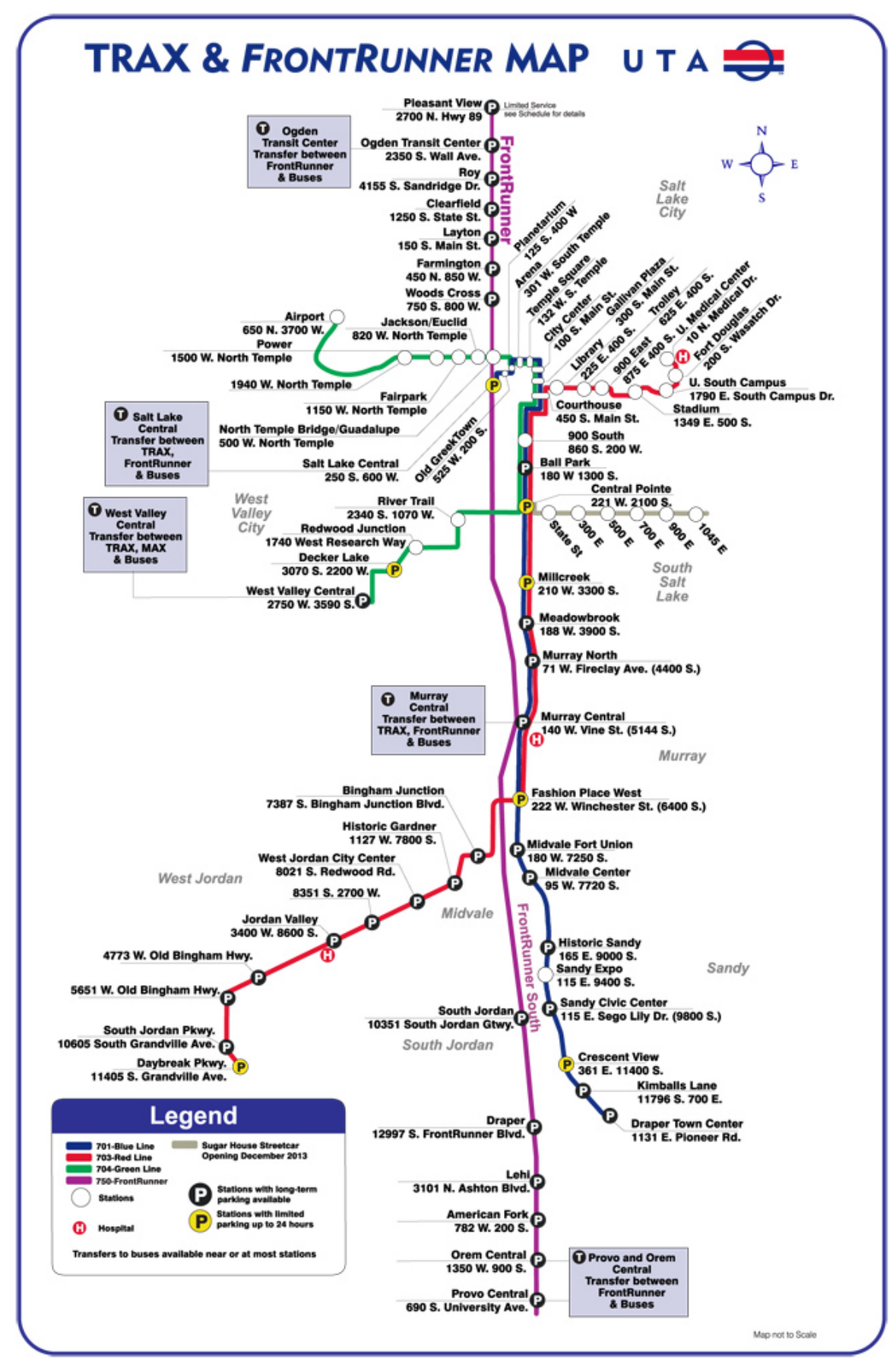

Figure 1. UTA Rail Systems Map

Table 1. Ridership on the UTA's Rail System (2012)

\begin{tabular}{|l|r|}
\hline TRAX & Nov 2011 - Oct 2012 \\
\hline Blue Line & 21,200 \\
\hline Red Line & 22,200 \\
\hline Green Line & 9,500 \\
\hline
\end{tabular}




\section{Quasi-Experimental Analysis}

A quasi-experiment is an empirical study used to estimate the causal impact of an intervention on its target population. Quasi-experimental research designs share some characteristics with traditional experimental designs, such as the treatment to one group but not another. Where the two designs differ is in the lack of random assignment of subjects to treatment and control groups.

A causal inference from any quasi-experiment must meet the basic requirements for all causal relationships: that cause precedes effect; that cause covaries with effect; and that alternative explanations for the causal relationships are implausible (Shadish et al. 2002). Both randomized and quasi-experiments force the treatment to occur before the effect. Assessing covariation between cause and effect is easily accomplished in all experiments, usually using statistical analysis. To meet the third requirement, randomized experiments make alternative explanations implausible by ensuring that subjects are randomly distributed across experimental conditions. Without random assignment, quasiexperiments rely on statistical control variables and sample matching to show that alternative explanations are implausible.

\section{The "Treatment"}

The "treatment" in this quasi-experiment is the 2.3 mile extension of TRAX from downtown Salt Lake City to Rice-Eccles Stadium in December 2001 (see Figure 2). Year 2001 represents the last year before the initial treatment, and 2002 represents the first year after the treatment. Construction began on the 1.5-mile University Medical Center Extension in May 2002, and the line opened at the end of September 2003. This opening constitutes a second treatment. The last year before this treatment is 2003, and the first year after is 2004 .

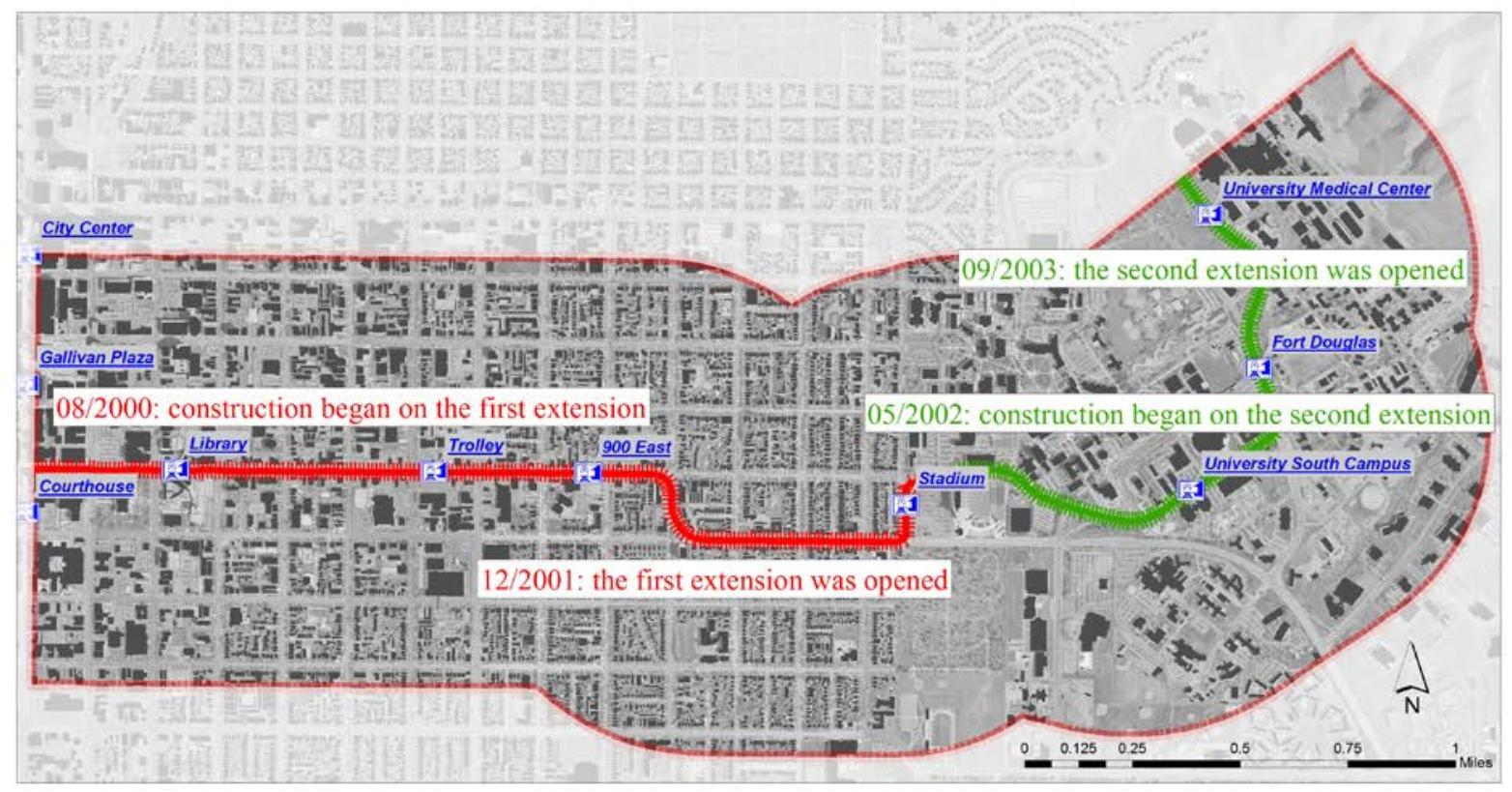

Figure 2. Timeline of the University TRAX Line 


\section{Traffic Counts}

The traffic counts used in this evaluation were provided by the Utah Department of Transportation (UDOT). Traffic data are analyzed and combined from various traffic counters throughout the state to obtain annual average daily traffic (AADT) numbers along with other traffic statistics such as design hour volume and directional factor. The Traffic Monitoring Unit collects traffic count data (48 hour mobile traffic counts) on a sample basis throughout the state and maintains the permanent counters as well. The counts from these sources are used by the Traffic Analysis Unit to obtain AADT numbers.

Mobile counts are completed using Wavetronix radar counters, Timemark, and Peek manufactured counters and hoses. To assure UDOT's permanent counters are working correctly, the operator visually reviews the data, along with the vehicle stream, to confirm that the loops are working normally and that counts being viewed are correct. Traffic counts are taken on all state highways and all federal aid eligible roadways. There are also classification counts used to determine truck traffic and establish axle correction factors for volume counts.

All traffic data received in the office is checked to see that all hours are accounted for and that the site description matches where the count was taken. AADTs are then calculated using 102 permanent counters throughout the state to develop temporal factors (daily and monthly), and are then expanded to the approximately 5,381 short time counts (48 hour).

Annual average daily traffic on 400/500 South, from UDOT counts, is presented in Table 2.

Table 2. Annual Average Daily Traffic on $400 / 500$ South and University Line Ridership

\begin{tabular}{|r|r|r|}
\hline Year & AADT & $\begin{array}{c}\text { University } \\
\text { Line Ridership }\end{array}$ \\
\hline 1992 & 31,539 & - \\
\hline 1993 & 32,133 & - \\
\hline 1994 & 32,795 & - \\
\hline 1995 & 33,408 & - \\
\hline 1996 & 33,758 & - \\
\hline 1997 & 36,247 & - \\
\hline 1998 & 38,533 & - \\
\hline 1999 & 41,347 & 3,836 \\
\hline 2000 & 32,393 & 8,009 \\
\hline 2001 & 32,801 & 9,441 \\
\hline 2002 & 23,488 & 12,395 \\
\hline 2003 & 23,916 & 14,410 \\
\hline 2004 & 22,692 & 15,005 \\
\hline 2005 & 22,667 & - \\
\hline 2006 & 23,432 & \\
\hline
\end{tabular}




\begin{tabular}{|l|l|l|}
2007 & 23,432 & 12,877 \\
\hline 2008 & 22,432 & 15,629 \\
\hline 2009 & 22,644 & 15,099 \\
\hline 2010 & 22,325 & 14,656 \\
\hline 2011 & 22,112 & 15,357 \\
\hline
\end{tabular}

\section{Short-Term Impact of TRAX - Pretest-Posttest without a Comparison Group}

Our first analysis uses the simplest quasi-experimental design, a one-group pre-treatment, posttreatment design with no comparison group. This can be diagrammed as follows, where the $O$ is an observation and the $X$ is a treatment. The "treatment" in this case is the opening of the University TRAX line.

$$
O_{1} \times O_{2}
$$

This research design is classified as a "weak" quasi-experimental design because it lacks a control or comparison group. "Adding a pretest provides weak information about the counterfactual inference about what might have happened to participants had the treatment not occurred...because [observation 1] occurs before [observation 2], the two may differ for reasons unrelated to treatment, such as maturation or history" (Shadish et al., 2002, p. 108). All of the difference in an outcome from before the treatment to after the treatment is attributed to the treatment itself.

In our case, all of the reduction in traffic on 400/500 South is attributed to the opening of the TRAX line. Maturation and history effects may be small if the pre-treatment date is immediately before TRAX opened, and the post-treatment date is immediately after TRAX opened. In this case, we can assume that the effect of the University TRAX line on traffic is just the drop in annual average daily traffic (AADT) on 400/500 South in the year before TRAX opened compared to the year after TRAX opened. This difference is $\Delta 1$ in Figure 3. The drop in AADT on 400/500 South was 9,300 vehicles per day (VPD) between 2001 and 2002. The line opened in December 2001, so we can assume that all of 2001 represents the before condition, and all of 2002 represents the after condition.

Several factors, however, complicate the picture. First, the AADT on 400/500 South was higher in prior years and had been increasing starting in 1992 and running through 1999. Construction of TRAX in 2000 and 2001, and the resulting disruption of traffic operations on 400/500 South, seem to have depressed AADT. If one assumes that the before condition is actually represented by AADT in 1999, the effect of TRAX is twice that estimated above, or $\Delta 2$. The decline in AADT between 1999 and 2002 was 17,900 VPD. 


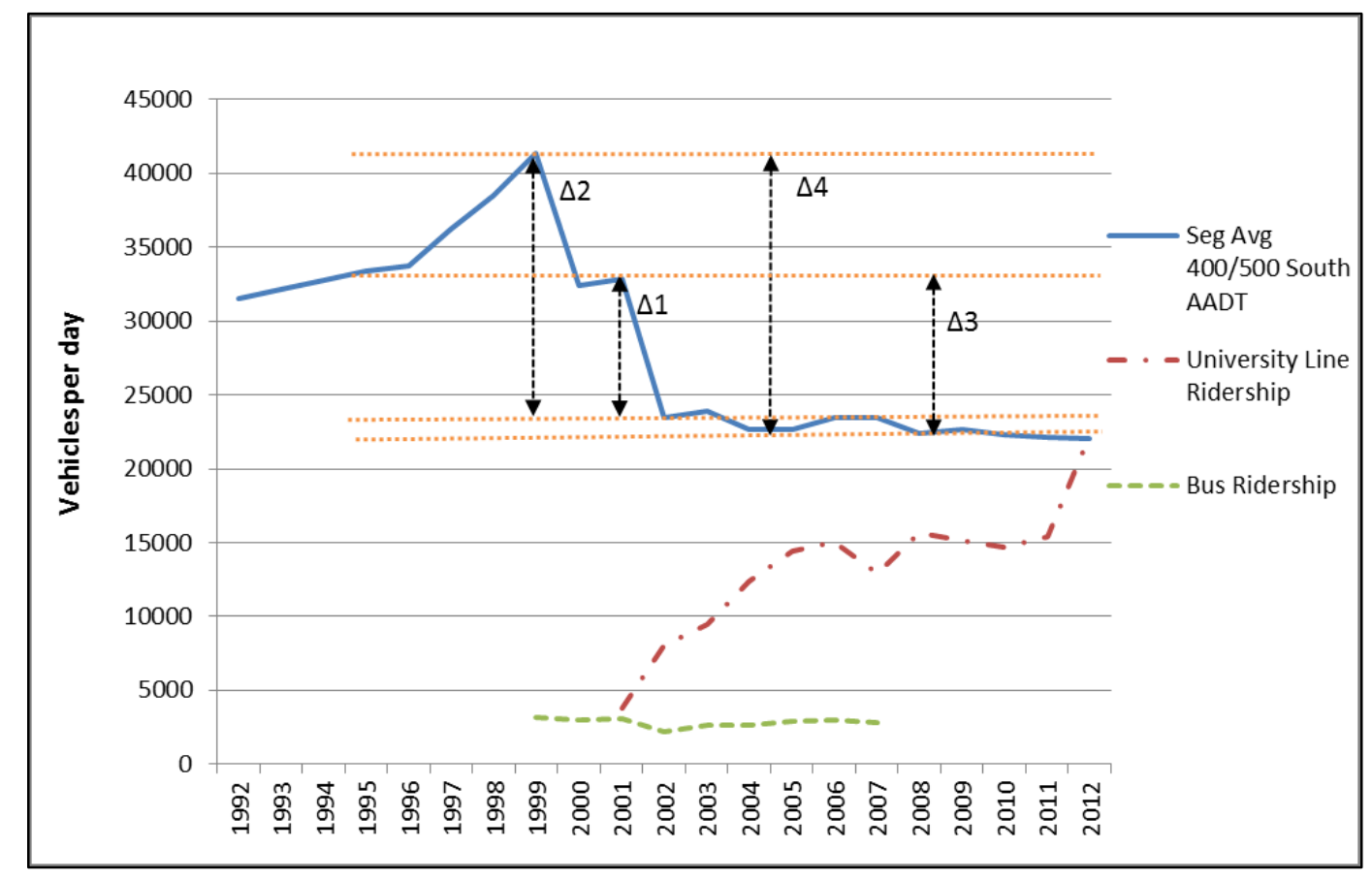

Figure 3. Average Daily Traffic on $400 / 500$ South, TRAX Ridership along $400 / 500$ South, and Bus Ridership along $400 / 500$ South

Table 3. Effect of TRAX on Traffic on $400 / 500$ South

\begin{tabular}{|l|r|r|}
\hline & AADT on 400 South & Net Transit Ridership \\
\hline$\Delta 1$ & $-9,300$ & 7,200 \\
\hline$\Delta 2$ & $-17,900$ & 7,100 \\
\hline$\Delta 3$ & $-10,100$ & 12,800 \\
\hline$\Delta 4$ & $-18,700$ & 12,000 \\
\hline
\end{tabular}

Second, traffic increased on some streets parallel to 400/500 South between 2001 and 2002, suggesting that not all of the decline on 400/500 S was due to TRAX but some was due to diversion to parallel streets. AADT increased slightly on $1300 \mathrm{~S}$ and $2100 \mathrm{~S}$ between 2001 and 2002, and was essentially level on other parallel streets. So most, but not all, of the reduction in AADT on 400 South appears to be due to TRAX. 


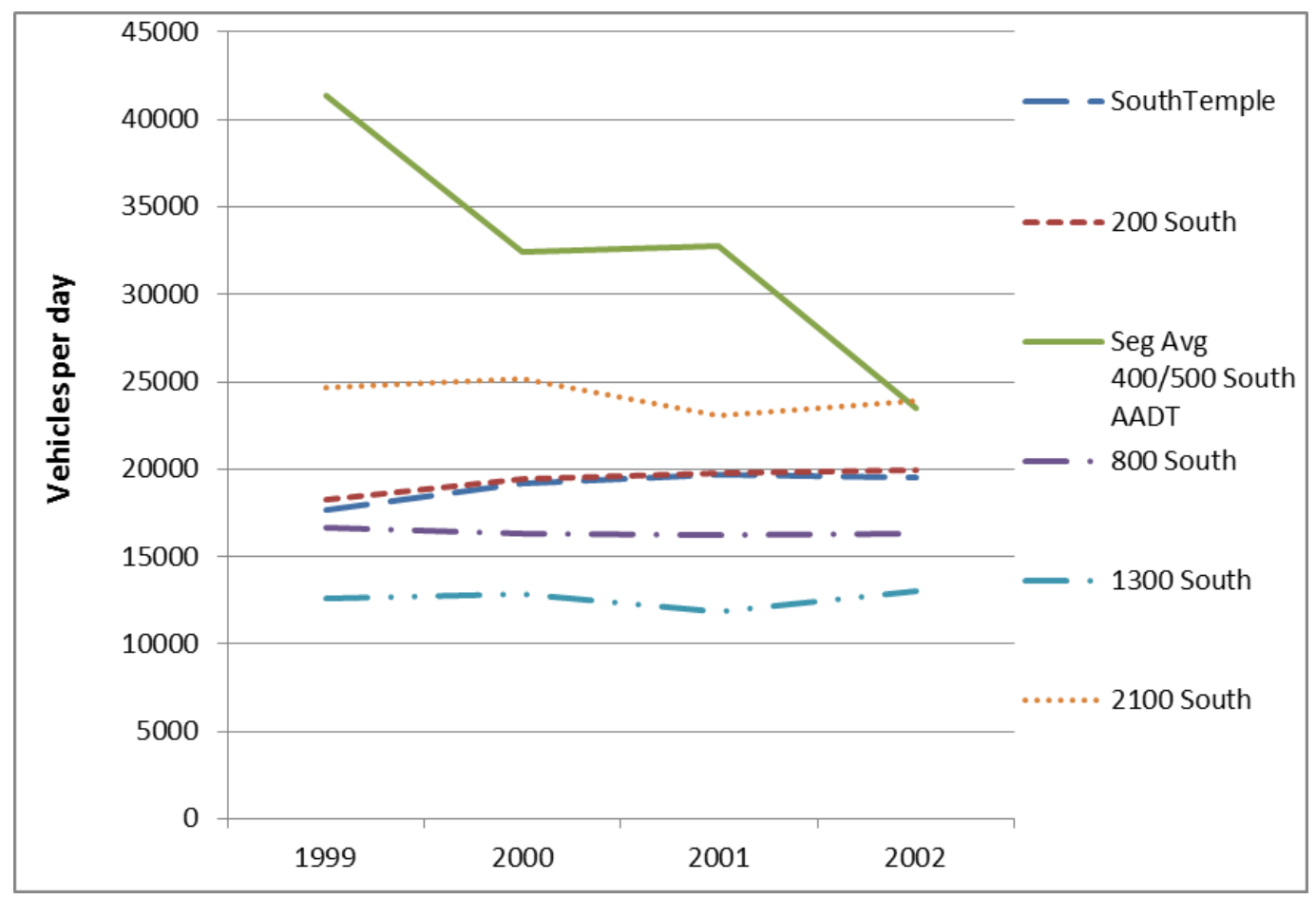

Figure 4. AADT on Streets Parallel to TRAX

Table 4. Change in AADT between 2001 and 2002

\begin{tabular}{|l|r|r|}
\hline & $\begin{array}{c}\text { Percentage Change in ADT } \\
\text { from 2001 to 2002 (\%) }\end{array}$ & $\begin{array}{r}\text { Distance from 400 South } \\
\text { (miles) }\end{array}$ \\
\hline South Temple & -0.7 & 0.76 \\
\hline 200 South & 0.63 & 0.46 \\
\hline Seg Avg 400/500 South AADT & -28.39 & 0.00 \\
\hline 800 South & 0.67 & 0.84 \\
\hline 1300 South & 9.89 & 1.52 \\
\hline 2100 South & 3.54 & 2.64 \\
\hline
\end{tabular}

Third, the reduction in VPD is greater than the net change in transit ridership of 7,200 riders. This net number is simply the ridership on TRAX in 2002 less the drop in bus ridership on routes along 400/500 South between 2001 and 2002. How could the impact of TRAX be greater than the net number of transit riders, even assuming that every TRAX rider would have driven a single-occupant vehicle (SOV)? On the subject of bus ridership, there were six bus lines running along 400/500 South from 1999 to 2001, and the total daily ridership was approximately 3,000 passengers. In August 2002, three bus lines were dropped, and two more were added. Total bus ridership declined, but only marginally. This is treated as a slight offset against TRAX ridership (see Table 5). 
Table 5. Bus Ridership on $400 / 500$ South

\begin{tabular}{|c|c|c|c|c|c|c|c|c|c|c|c|c|c|c|c|c|}
\hline \multicolumn{17}{|c|}{ Criteria: west-east direction; through $400 / 500$ south } \\
\hline \multirow{2}{*}{ Line } & \multirow{2}{*}{ Line Name } & \multirow{2}{*}{1999} & \multirow{2}{*}{2000} & \multirow{2}{*}{2001} & \multicolumn{2}{|c|}{2002} & \multirow{2}{*}{2003} & \multirow{2}{*}{2004} & \multirow{2}{*}{2005} & \multirow{2}{*}{2006} & \multicolumn{2}{|c|}{2007} & \multirow{2}{*}{2008} & \multirow{2}{*}{2009} & \multirow{2}{*}{2010} & \multirow{2}{*}{2011} \\
\hline & & & & & 2002.08 & 2002.08 & & & & & 2007.08 & 2007.08 & & & & \\
\hline 13 & CANYON RIM & 460 & 495 & 462 & 353 & & & & & & & & & & & \\
\hline 14 & EAST MILLCREEK & 606 & 686 & 604 & 454 & 704 & 687 & 724 & 778 & 806 & 708 & & & & & \\
\hline 29 & WASATCH BLVD VIA U. OF UTAH & 459 & & & & & & & & & & & & & & \\
\hline 52 & UNIVERSITY OF UTAH & 1109 & 1061 & 1088 & 739 & & & & & & & & & & & \\
\hline 54 & OLYMPUS COVE & 93 & 299 & 435 & & & & & & & & & & & & \\
\hline 55 & UOFU/DAVIS CTY./WEBER ST. & & & & & 1089 & 1176 & 1193 & 1221 & 1222 & 1147 & & & & & \\
\hline 71 & CENTERVILLE VIA ORCHARD DRIVE & & & & & 228 & 260 & 244 & 311 & 398 & 340 & & & & & \\
\hline 73 & HIGHWAY 89 EXPRESS & 333 & 367 & 386 & 374 & 420 & 455 & 443 & 525 & 543 & 554 & & & & & \\
\hline 129 & UOFU/FOOTHILL DRIVE NITE RIDE & 131 & 127 & 104 & 59 & 66 & 65 & 54 & 51 & 66 & 53 & & & & & \\
\hline 228 & FOOTHILL BLVD / 2700 EAST & & & & & & & & & & & & & & & $\mathrm{Y}$ \\
\hline 455 & U OF U/DAVIS COUNTY/WSU & & & & & & & & & & & $\mathrm{Y}$ & $\mathrm{Y}$ & $\mathrm{Y}$ & $\mathrm{Y}$ & $\mathrm{Y}$ \\
\hline 471 & CENTERVILLE VIA ORCHARD DRIVE & & & & & & & & & & & $\mathrm{Y}$ & $\mathrm{Y}$ & & & \\
\hline \multirow[t]{3}{*}{473} & SLC - OGDEN HWY 89 EXPRESS & & & & & & & & & & & $\mathrm{Y}$ & $\mathrm{Y}$ & $\mathrm{Y}$ & $\mathrm{Y}$ & $Y$ \\
\hline & & & & & 1978 & 2506 & & & & & & & & & & \\
\hline & SUM & 3191 & 3034 & 3080 & \multicolumn{2}{|c|}{2242} & 2642 & 2658 & 2887 & 3035 & 2802 & & & & & \\
\hline
\end{tabular}

If one adds the net transit ridership increase between 2001 and 2002 to the net increase in AADT on parallel streets (mainly 1300 South and 2100 South), one arrives at a number roughly equivalent to the drop in AADT on $400 / 500$ South. Specifically, the decline in AADT on $400 / 500$ South $(9,300)$ is roughly equal to the increase in transit ridership $(7,200)$ plus the increase in AADT on parallel streets $(2,100)$. This simple accounting gives a rough order of magnitude estimate of TRAX's impact on traffic.

\section{Medium-Term Impact of TRAX - Pretest-Posttest with a Comparison Group}

Figure 3 shows that TRAX ridership continued to increase after 2002. Part of that increase is doubtless due to the extension of the University TRAX line to the $U$ of $U$ Medical Center in late September 2003. This extension added three stops and 1.5 miles to the line. You can see a small dip in AADT on 400 South between 2003 and 2004. You can also see a bump up in TRAX ridership between 2003 and 2004. However, TRAX ridership also increased between 2002 and 2003, before the extension opened, and after 2004, when the full line was in operation. Ridership doesn't level off until 2008-2011. The dip in 2007 is likely due to issues with a passenger counting system that UTA implemented in 2007, as well as construction in downtown Salt Lake City and consumers' willingness to pay higher prices for gasoline, according to an article from the Deseret News (Warburton, 2007).

New transit lines often have a break-in period when travel patterns evolve as riders "discover" the new transit option. To estimate the longer-term impact of TRAX on traffic, we need to account for general trends in the study area. This requires a more sophisticated quasi-experimental design, a design that includes both a pre-treatment observation and a control or comparison group. According to the "bible" of quasi-experimental design, Shadish, Cook, and Campbell's Experimental and Quasi-Experimental Designs for Generalized Causal Inference, "The joint use of a pretest and a comparison group makes it easier to examine certain threats to validity [causal inference]. Because the groups are nonequivalent by definition, selection bias is presumed to be present. The pretest allows exploration of the possible size and direction of that bias...." (Shadish et al., 2002, p.138). 
This is typically done by seeing if the treatment and control groups differ significantly before the treatment. The absence of pre-treatment difference in a quasi-experiment doesn't prove that selection bias is absent, but it makes it less likely. In particular, it reduces the likelihood of a statistical problem called regression-to-the-mean. Regression-to-the-mean is the statistical tendency of values above the mean in one period to gravitate downward toward the mean in the next period, and those below the mean in one period to gravitate upward toward the mean in the next period.

Ideally, we would match 400 South with another street that is very similar to 400 South before the University TRAX line opened. It would be a street not particularly affected by the line. The two streets that mostly closely match 400 South are 700 East and 1300 East (see Figure 5). These are north-south streets that intersect TRAX but do not offer park-and-ride options, and hence, should not be appreciably affected by the opening of the University TRAX line. Like 400 South, 700 East is a six-lane arterial serving the northeast quadrant of the city. However, 700 East carried significantly more traffic, even before TRAX. Like 400 South, 1300 East serves the university directly. However, 1300 East only had four lanes before the opening of TRAX, and carried much less traffic. Interestingly, it now carries almost as much traffic as 400 South, yet is down to three lanes south of campus after a "road diet" narrowing in 2009.

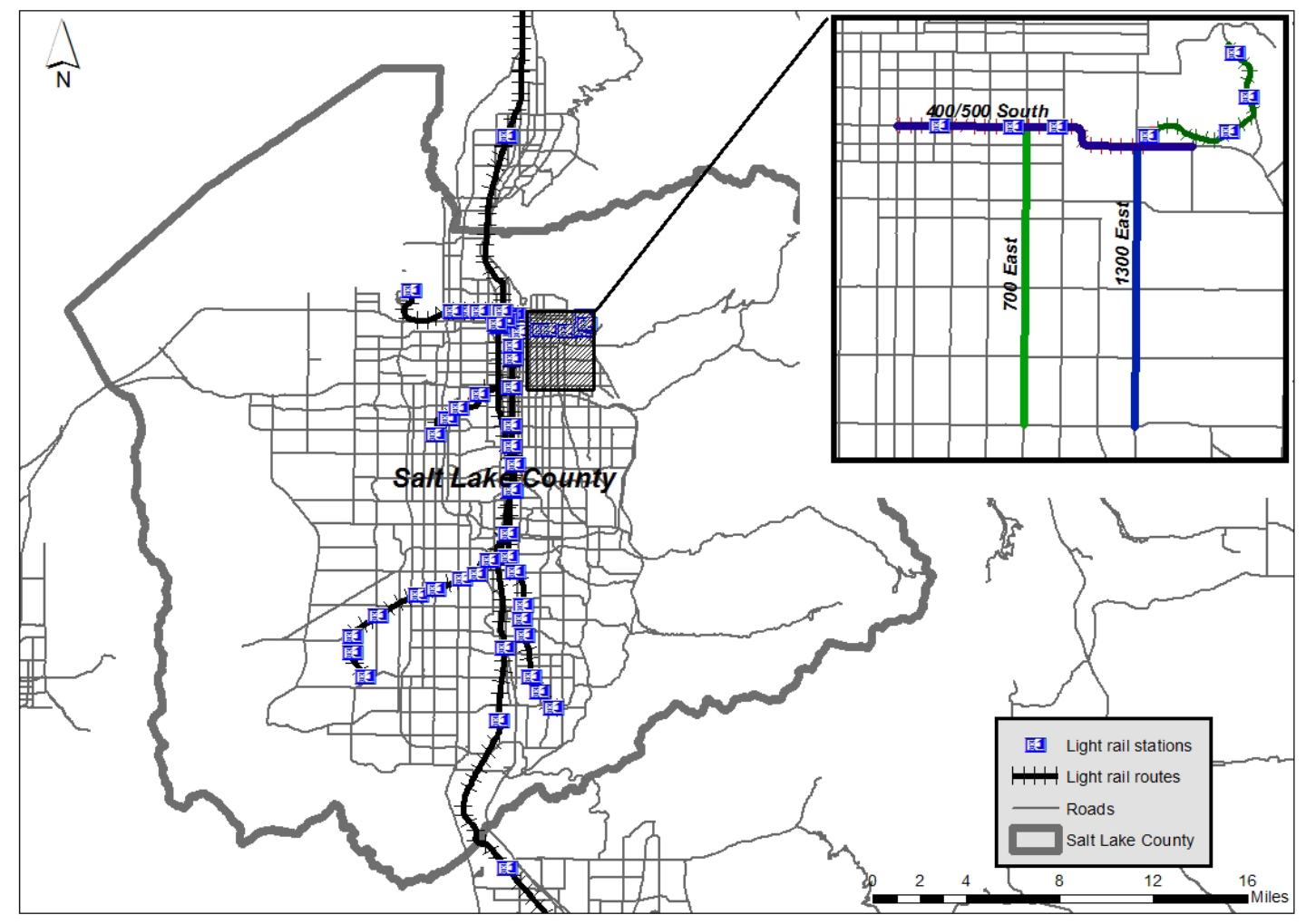

Figure 5. 400/500 South and Comparison Roads (700 East and 1300 East)

Although neither 700 East or 1300 East is a perfect match to 400 South, it turns out, however, that the average AADT on these two streets was virtually identical to the AADT on 400 South before the University TRAX line opened. We will use this average as our control in this quasi-experimental analysis. As can be seen in Figure 6, the average AADT for the two streets dips after 2001, as it does on 400 
South. But it doesn't dip as far. It is not clear why traffic volumes would decline on these two streets, but this trend needs to be accounted for in a pretest-posttest design with a comparison group.

Assuming the counterfactual that traffic on 400 South would have tracked exactly with these two streets in the absence of TRAX, $\triangle 5$ becomes our estimate of the reduction in traffic on 400 South due to TRAX. For the years 2006-2012, the average AADT on these two north-south streets was 7,500 VPD higher than the AADT on 400 South. This is less than our estimates in a simple pre-treatment, post-treatment comparison of traffic on 400 South, and represents a better estimate than attainable with the simpler design.

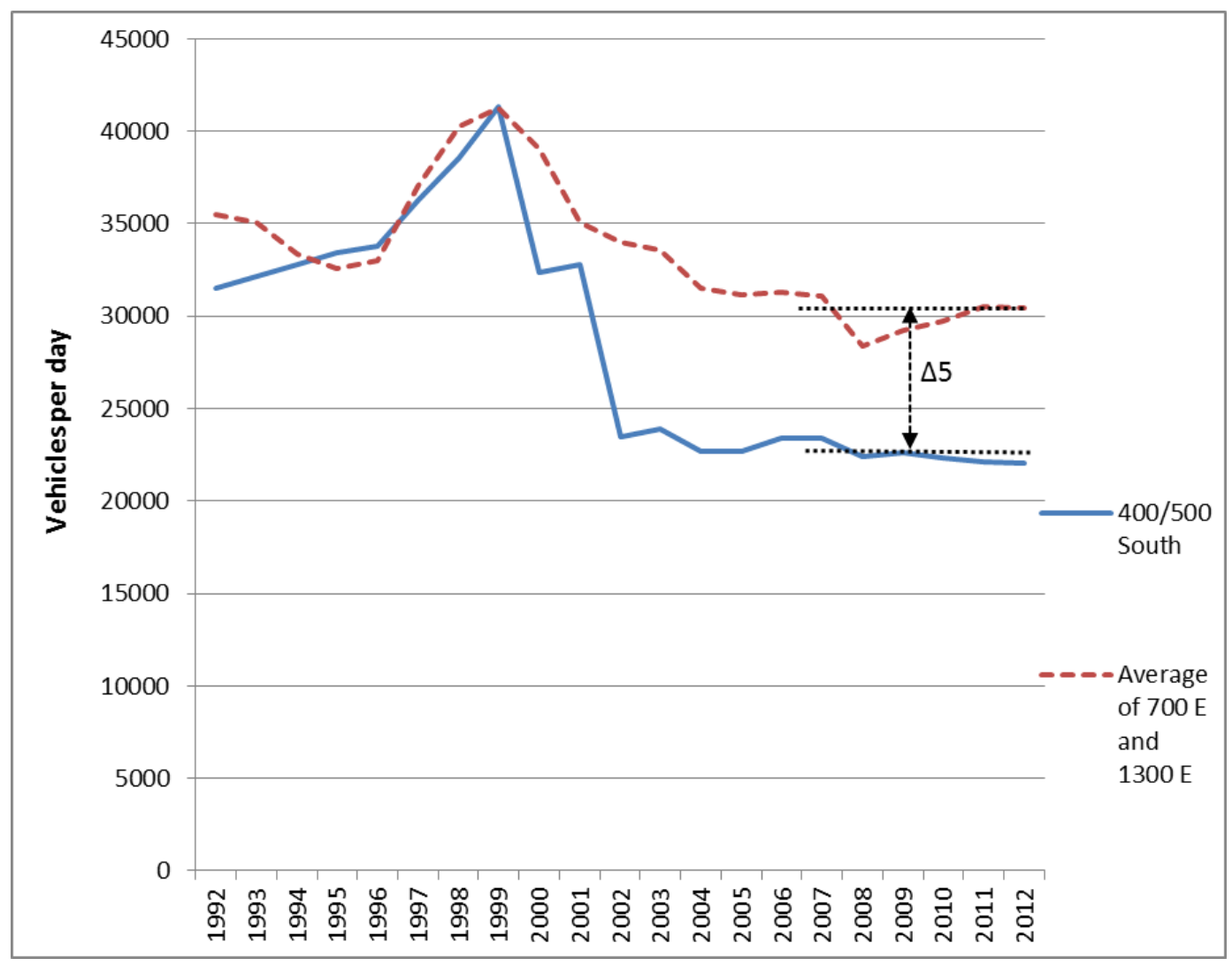

Figure 6. Average AADT on 700 East and 1300 East

We can check this long-run estimate of TRAX's impact on 400 South's traffic against transit ridership. The net transit ridership increase between 2001 and 2006-2012 is 12,700 passengers per day $(15,800$ average for 2006-2012 minus 3,100 for 2001). Specifically, the decline in AADT on 400/500 South $(7,500)$ is 41 percent less than the increase in transit ridership. This simple accounting comparison makes the estimate of TRAX's impact seem plausible. The drop in AADT on 400/500 South would necessarily be less than the increase in transit ridership since not every transit trip replaces a drive-alone vehicle trip.

\section{Land-Use Changes}

A final quasi-experimental analysis assumes that, without TRAX, traffic on the 400/500 South would have increased proportionally with development in the corridor, or more specifically, increased 
proportionally with traffic generated by that development. For this analysis, the corridor is assumed to extend a half-mile north and south of 400/500 South, to South Temple on the north and 800 South on the south (see Figure 7). Parcels that changed between 1999 and 2009 (were developed, redeveloped, or cleared) are highlighted in yellow.

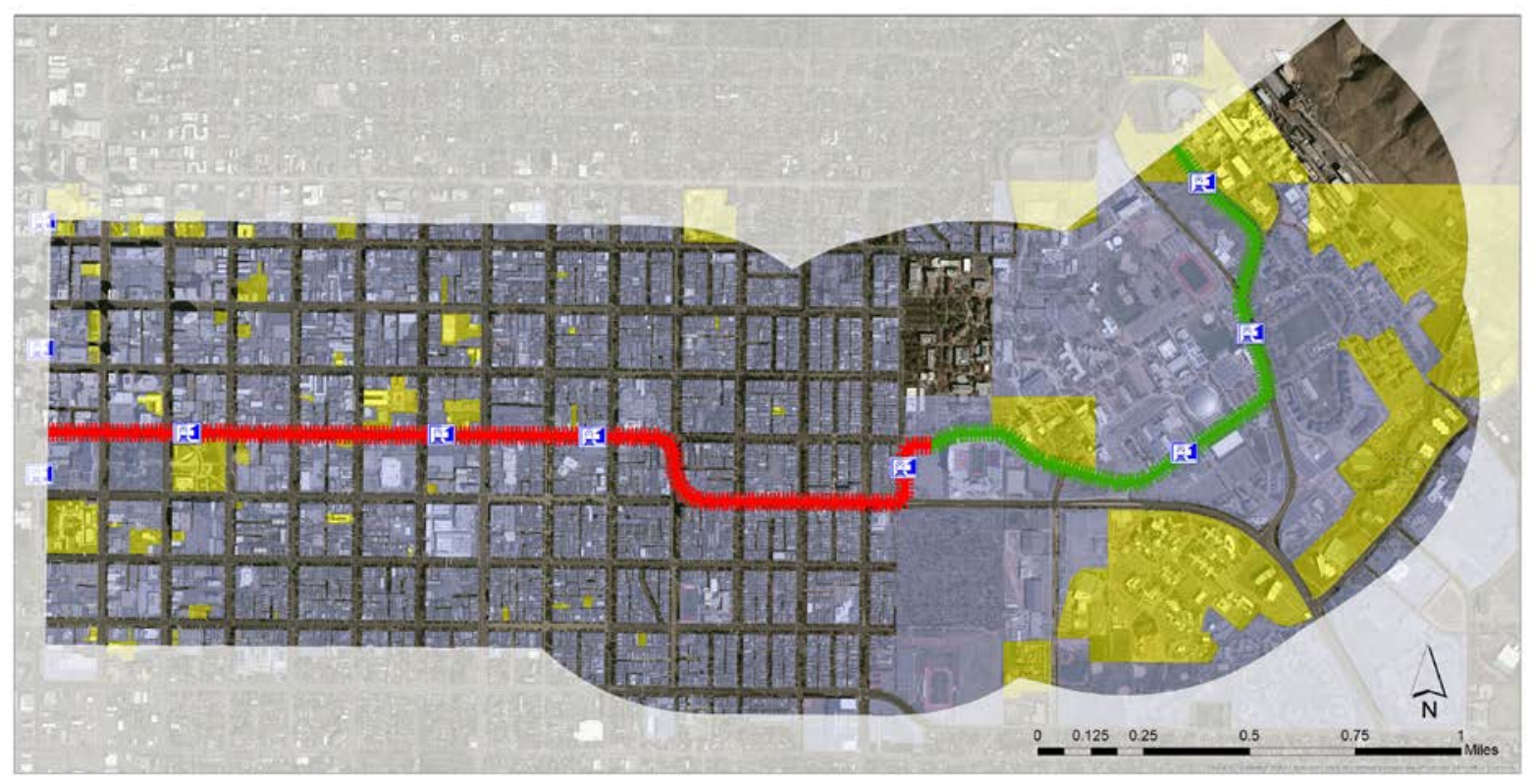

Figure 7. Parcels that Changed between 1999 and 2009 (highlighted in yellow)

We were able to identify changes by comparing aerial photos for 1999 and 2009, parcel-by-parcel, and also by comparing tax assessor records for the two years. Building floor area is available from tax assessor records only for 2009. Building floor area in 1999 was set equal to that in 2009 where the building footprint didn't change. Where the footprint did change, floor area in 1999 was estimated from the 1999 aerial photo assuming buildings were single story.

Building floor area changes in the 400/500 South corridor are summarized in Table 6 . The appendix has a complete list of parcels that experienced changes. The vast majority of the changes involved construction on vacant land (99 of 269 parcels). And the vast majority of new development was commercial, followed by public and then other (which includes parking lots).

Table 6. Changes of Building Floor Area by Land-Use Type between 1999 and 2009 for Parcels that Changed

\begin{tabular}{|l|r|r|r|}
\hline & \multicolumn{1}{|c|}{$\mathbf{1 9 9 9}$} & \multicolumn{1}{c|}{$\mathbf{2 0 0 9}$} & \multicolumn{1}{c|}{ changes } \\
\hline Residential & 48,300 & 794,000 & 745,800 \\
\hline Commercial & $1,712,200$ & $4,870,500$ & $3,158,400$ \\
\hline Public & $10,854,100$ & $13,445,000$ & $2,590,900$ \\
\hline Other (e.g., parking lots) & 46,800 & 3,500 & $-43,400$ \\
\hline Total building square footage & $12,661,400$ & $19,113,000$ & $6,451,700$ \\
\hline
\end{tabular}


Table 7 provides a summary of total development in the corridor, by land-use type, in 1999 and 2009 . The gross floor area of all buildings increased from 50,567,600 square feet to 57,019,200 square feet over the decade, an increase of 6,451,700 square feet or 12.8 percent. It is impossible to say how much of that additional development was due to TRAX. However, we can say that the corridor became more developed over the decade, concurrent with the opening of TRAX, and that surprisingly, traffic on $400 / 500$ South actually declined despite increased development in the corridor. We are aware of no similar finding in the literature.

Table 7. Total Building Floor Area in the $\mathbf{4 0 0 / 5 0 0 ~ S o u t h ~ C o r r i d o r ~ b y ~ L a n d - U s e ~ T y p e ~}$

\begin{tabular}{|l|r|r|r|}
\hline & 1999 & \multicolumn{1}{|c|}{$\mathbf{2 0 0 9}$} & \multicolumn{1}{c|}{ changes } \\
\hline Residential & $11,173,000$ & $11,918,800$ & 745,800 \\
\hline Commercial & $19,851,100$ & $23,009,400$ & $3,158,400$ \\
\hline Public & $16,424,000$ & $19,014,900$ & $2,590,900$ \\
\hline Other & $3,119,500$ & $3,076,100$ & $-43,400$ \\
\hline Total building square footage & $50,567,600$ & $57,019,200$ & $6,451,700$ \\
\hline
\end{tabular}

Using trip-generation rates from the Institute of Transportation Engineers' (ITE) Trip Generation report, we estimated total trips generated by properties within the 400/500 South Corridor. ${ }^{1}$ Trip generation totals by land-use type are presented in Table 8. Trips rates from ITE actually refer to trip ends, either origins or destinations. Trips beginning in the corridor and destined outside are counted only once. Trips beginning outside the corridor and destined inside are also counted only once. Those beginning and ending within the corridor are counted twice. And those simply traveling through the corridor, with origins and destinations outside, aren't captured at all with our method. Hence there is no simple oneto-one relationship between trips generated within the corridor, and traffic on 400/500 South.

Table 8. Total Trip Generation by Land-Use

\begin{tabular}{|l|r|r|r|}
\hline & 1999 & 2009 & Changes \\
\hline Residential & 77,000 & 86,200 & 9,200 \\
\hline Commercial & 834,500 & 861,000 & 26,500 \\
\hline
\end{tabular}

\footnotetext{
${ }^{1}$ For University of Utah trip generation, we categorized university buildings into four classes: hospital, university housing, research park and main campus. Trip rates are 16.5 per 1000 square feet for the hospital, 6.11 per 1000 square feet for the research park, 1.71 per student, and 8.96 per employee for the main campus. For university housing, the trip rate depends on the type of the housing, such as dorms, apartments and family houses. Total trip generation for the main campus is shown below.
}

\begin{tabular}{|l|l|l|l|l|l|}
\hline & \multicolumn{2}{|c|}{ Students } & \multicolumn{2}{c|}{ Employees } & \multirow{2}{*}{ Trips } \\
\cline { 2 - 5 } & Number & Trip rate & number & Trip rate & \\
\hline 1999 & 25,781 & 1.71 & 3,070 & 8.96 & 71,600 \\
\hline 2009 & 29,284 & 1.71 & 3,582 & 8.96 & 82,200 \\
\hline
\end{tabular}




\begin{tabular}{|l|r|r|r|} 
Public & 226,100 & 276,500 & 50,400 \\
\hline Other & 500 & 4,400 & 3,900 \\
\hline Total & $1,138,100$ & $1,228,100$ & 90,000 \\
\hline
\end{tabular}

Nonetheless, we can assume that in the absence of TRAX, there would be rough proportionality between traffic generated within the corridor and non-thru traffic on 400/500 South. If the former increases by 7.9 percent, as we have calculated, it is reasonable to assume that traffic on the main eastwest street through the corridor would also increase by 7.9 percent. The regional travel model predicts that 1.4 percent of the traffic on $400 / 500$ South is thru-traffic, leaving 98.6 percent $(40,800)$ as local. ${ }^{2}$ So for our last estimate of TRAX's impact on traffic, we assume a counterfactual that local traffic on 400/500 South would have increased by 7.9 percent in the absence of TRAX, from 40,800 in 1999 (98.6 percent of actual count) to 44,000 in $2009(1.079 * 40,800)$. The difference between this estimate for 2009 and our estimate of actual local traffic volume in 2009 (22,300), 21,700 (44,000-22,300) is the estimated effect of TRAX. It is shown as $\Delta 6$ in Figure 8 . Note that these numbers explicitly exclude thrutraffic between State Street on the west and Guardsman Way on the east.

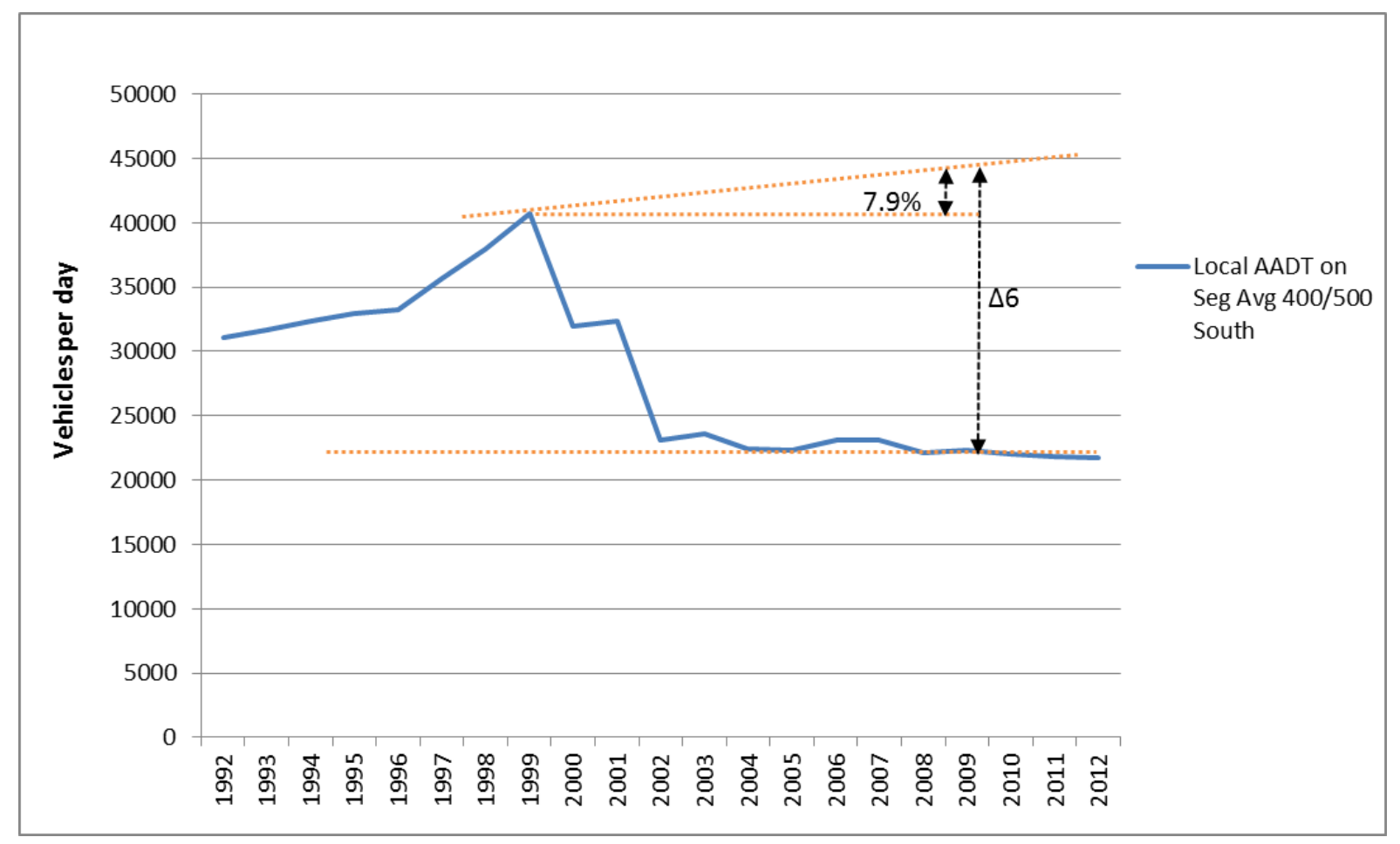

Figure 8. Local AADT on 400/500, Estimated Local Traffic on 400/500 Based on the Trip Generation between 1999 and 2009

\footnotetext{
2 The regional model shows that there are about 2,200 trips a day between downtown (defined as the area between State and I-15 and South Temple and 900 South) and the area east of Guardsman Way and North of 900 South. This accounts for $1.4 \%$ of the east/west trips within $1 / 2$ mile of 400 South.
} 


\section{Energy and Emission Reduction}

To summarize, we have six estimates of the impact of TRAX on average daily traffic on 400/500 South, all based on different assumptions and different time frames (see Table 9). We chose a conservative estimate that is roughly mid-range, 14,000 vehicles per day, for this summary of impacts.

Table 9. Estimates of Traffic Reduction on $400 / 500$ South Due to TRAX

\begin{tabular}{|c|c|}
\hline Estimate & Average Daily Traffic Reduction \\
\hline$\Delta 1$ & 9,300 \\
\hline$\Delta 2$ & 17,900 \\
\hline$\Delta 3$ & 10,100 \\
\hline$\Delta 4$ & 18,700 \\
\hline$\Delta 5$ & 7,300 \\
\hline$\Delta 6$ & 21,700 \\
\hline
\end{tabular}

With the traffic decrease on $400 / 500$ South, there is less fuel consumed and less pollution emitted. According to EPA data, the average emissions and fuel consumption for passenger cars are shown in Table 10. Multiplying the reduction in vehicle miles by the fuel consumption and pollutant emissions per vehicle mile in Table 10, we obtain the results in Table 11. Due to TRAX, 1,300 gallons of gasoline are saved and 26,100 pounds of $\mathrm{CO}_{2}$ emission aren't emitted each day. Annually, this translates to saving 487,700 gallons of gasoline and not emitting 9,537,000 pounds of $\mathrm{CO}_{2}$.

Table 10. EPA Average Emissions and Fuel Consumption for Passenger Cars

\begin{tabular}{|c|c|}
\hline Pollutant/Fuel & Emission \& Fuel Consumption Rates (per mile driven) \\
\hline $\mathrm{VOC}$ & 1.034 grams $(\mathrm{g})$ \\
\hline $\mathrm{THC}$ & $1.077 \mathrm{~g}$ \\
\hline $\mathrm{CO}$ & $9.400 \mathrm{~g}$ \\
\hline $\mathrm{NO}_{\mathrm{x}}$ & $0.693 \mathrm{~g}$ \\
\hline $\mathrm{CO}_{2}$ & $368.4 \mathrm{~g}$ \\
\hline Gasoline Consumption & 0.04149 gallons (gal) \\
\hline
\end{tabular}

Source: Average Annual Emissions and Fuel Consumption for Gasoline-Fueled Passenger Cars and Light Trucks, EPA, http://www.epa.gov/otaq/consumer/420f08024.pdf. 
Table 11. Effect of TRAX on Energy Consumption and Emission Reduction

\begin{tabular}{|c|c|c|c|c|c|}
\hline $\begin{array}{l}\text { Pollutant } \\
\text { /Fuel }\end{array}$ & $\begin{array}{c}\text { Emission \& Fuel } \\
\text { Consumption Rates } \\
\text { (per mile driven) }\end{array}$ & $\begin{array}{c}\text { Traffic } \\
\text { Reduction }\end{array}$ & Calculation & $\begin{array}{c}\text { Daily Reduction } \\
\text { of Emission } \& \\
\text { Fuel } \\
\text { Consumption }\end{array}$ & $\begin{array}{c}\text { Annual } \\
\text { Reduction of } \\
\text { Emission \& Fuel } \\
\text { Consumption }\end{array}$ \\
\hline VOC & 1.034 grams $(\mathrm{g})$ & \multirow{6}{*}{$\begin{array}{l}14000 \\
\text { vehicles } \\
\text { per day } \\
\text { (vpd) }\end{array}$} & $(1.034 \mathrm{~g} / \mathrm{mi}) \times(2.3 \mathrm{mi}) \times(14000 \mathrm{vpd}) \times(1 \mathrm{lb} . / 454 \mathrm{~g})$ & $73.34 \mathrm{lb}$ & $26,800 \mathrm{lb}$. \\
\hline THC & $1.077 \mathrm{~g}$ & & $(1.077 \mathrm{~g} / \mathrm{mi}) \times(2.3 \mathrm{mi}) \times(14000 \mathrm{vpd}) \times(1 \mathrm{lb} . / 454 \mathrm{~g})$ & $76.39 \mathrm{lb}$. & $27,900 \mathrm{lb}$. \\
\hline $\mathrm{CO}$ & $9.400 \mathrm{~g}$ & & $(9.400 \mathrm{~g} / \mathrm{mi}) \times(2.3 \mathrm{mi}) \times(14000 \mathrm{vpd}) \times(1 \mathrm{lb} . / 454 \mathrm{~g})$ & $666.70 \mathrm{lb}$. & $243,300 \mathrm{lb}$. \\
\hline $\mathrm{NO}_{\mathrm{x}}$ & $0.693 \mathrm{~g}$ & & $(0.693 \mathrm{~g} / \mathrm{mi}) \times(2.3 \mathrm{mi}) \times(14000 \mathrm{vpd}) \times(1 \mathrm{lb} . / 454 \mathrm{~g})$ & $49.15 \mathrm{lb}$. & $18,000 \mathrm{lb}$. \\
\hline $\mathrm{CO}_{2}$ & $368.4 \mathrm{~g}$ & & $(368.4 \mathrm{~g} / \mathrm{mi}) \times(2.3 \mathrm{mi}) \times(14000 \mathrm{vpd}) \times(1 \mathrm{lb} . / 454 \mathrm{~g})$ & $26,100 \mathrm{lb}$. & $9,537,000 \mathrm{lb}$. \\
\hline $\begin{array}{c}\text { Gasoline } \\
\text { Consump } \\
\text { tion }\end{array}$ & $\begin{array}{c}0.04149 \text { gallons } \\
\text { (gal) }\end{array}$ & & $(2.3 \mathrm{mi}) \times(14000 \mathrm{vpd}) /(24.1 \mathrm{mi} / \mathrm{gal})$ & 1,300 gal & 487,700 gal \\
\hline
\end{tabular}

The University of Utah also saves substantially on parking spaces and associated costs. Assuming half of the reduction in traffic on $400 / 500$ South are trips made to the university, and the average cost of a surface parking space is $\$ 4,000$ (Litman, 2013), ${ }^{3}$ the savings on construction costs alone total $\$ 4,000$ per space times 6,000 spaces, or \$23.6 million. The annual operating and maintenance cost savings (again, according to Litman, 2013) would total $\$ 282$ per space times 6,000 spaces, or $\$ 1.7$ million annually.

\section{Conclusion and Discussion}

There is an important debate over the value of LRT for mitigation of traffic congestion, energy consumption, and air pollution. To accurately assess LRT effect on traffic it is necessary to use a quasiexperiment analysis. A cross sectional analysis (of the sort that is so common in ridership modeling) can only establish correlation, not causal inference). This study provides some of the strongest evidence to date of LRT effects on traffic, energy consumption, and air pollution. We found other studies in our literature review that also attempt to measure and quantify the impacts of LRT on traffic congestion, but none of these other studies used a controlled quasi-experimental research design. Our quasi-experiment focuses on the "treatment" of introducing the 2.3 mile extension of the TRAX system with service continuing from Downtown Salt Lake City to the Rice-Eccles Stadium on the University of Utah campus in December 2001, and the additional 1.5 mile extension to the University Medical Center September 2003.

In the short-term analysis, we found that between 2001 and 2002, after the introduction of the "treatment", the AADT on 400/500 South decreased by 9,300 vehicles per day (VPD). This is roughly equal to the increase in transit ridership $(7,200)$ and the increase in AADT on parallel streets $(2,100)$. When this comparison was drawn out to 1999, we found that the decrease in AADT was 17,900 VPD.

\footnotetext{
${ }^{3}$ In Litman's (2013) report, the cost was reported as 1997 U.S. Dollars. In this report, we converted the costs to 2012 U.S. Dollars by Consumer Price Index (CPI). The CPI has increased by 1.43 times from 1997 to 2012.
} 
TRAX ridership had been growing prior to the extension of the line to the Rice-Eccles Stadium, but it continued to increase after 2002 before leveling off during 2008-2012.

In the medium-term analysis, we compared two streets that we consider to be comparable to $400 / 500$ South before the University TRAX line opened: 1300 East and 700 East, which virtually had identical average AADT to 400/500 South. The results showed that the average AADT on these two streets was 7,500 VPD higher than the AADT on 400/500 South after the TRAX line opened (between 2006 and 2012).

In the final quasi-experimental analysis, the building square footage increased 12.8 percent between 1999 and 2009 in the half-mile buffer around 400/500 South. Accordingly, 7.9 percent new trips are generated by these new developments on the corridor. Our estimates indicated that VPD should have been 44,000 on this corridor, but instead we found this number to be 22,300 . Therefore, because of TRAX, the VPD is reduced by 21,700 . Based on our estimates, LRT along $400 / 500$ South saves almost 500,000 gallons of gasoline and prevents almost 10 million pounds of $\mathrm{CO}_{2}$ from being emitted each year.

AADT on 400/500 South has been relatively steady since 2005. The theory of induced traffic suggests that, in the very long-term, the road will fill to capacity due to redevelopment in the corridor and additional development in the region. However, the university is not planning to expand its enrollments, and there is only so much redevelopment that can occur within the corridor given the normal useful lives of buildings (hundreds of years for residential properties, decades for nonresidential properties). Perhaps the best chance for redevelopment is the conversion of surface parking lots to active uses with structured parking, which has already begun to occur (for example, at Trolley Square). Nonetheless, we would be hard pressed to project when traffic volumes will begin to increase in the corridor, and see no evidence of it through 2012, 10 years after line was extended to the University Medical Center.

This study is subject to important caveats. One is in regard to the external validity of this study, or lack thereof. We cannot guarantee that LRT would have the same effect on traffic at other locations given that our study area (from downtown Salt Lake City to University of Utah) is unique. The University of Utah is a major center of employment for Salt Lake City and the surrounding county, and students and staff have free access to TRAX. Locations with employers who do not subsidize the cost of riding LRT may not see the ridership levels and decreases in vehicle travel trips that the university does.

More important is a caveat related to internal validity. Our design is quasi-experimental, not experimental, and hence we must be careful not to overstate our ability to draw causal inferences. The dip in traffic on 400/500 South could, theoretically, be due to some cause other than the extension of TRAX to the university. There are numerous threats to the validity of the simple pre-intervention, postintervention comparison without a control group (Shadish et al. 2002). The two control groups used in this quasi-experimental design (parallel streets in Figure 4 and perpendicular streets in Figure 6) are not, of course, a perfect match with 400/500 South, the treated street. Other factors (such as different redevelopment patterns in their corridors) could cause them to have different traffic patterns than $400 / 500$ South in the absence of TRAX. "A counterfactual is something that is contrary to fact. In an experiment, we observe what did happen when people received a treatment (in this case, the 
availability of LRT service). The counterfactual is knowledge of what would have happened to those same people if they simultaneously had not received treatment. An effect (of a treatment) is the difference between what did happen and what would have happened" (Shadish et al. 2002, p. 5). We cannot actually observe a counterfactual, but instead select a control group that comes as close to representing the counterfactual as possible. What would have happened in the absence of LRT in the transit corridor? We have simply chosen streets that serve the same quadrant of the region (NE Salt Lake City), and should be affected by the same forces when it comes to traffic. In a quasi-experimental design like this one, the control group (actually comparison group) is never identical to the experimental group. If it were, this would be a true experiment. Also, we have estimated traffic reduction several ways, in an attempt to bound likely impacts of TRAX. That is, we have established several counterfactuals for purposes of the quasi-experiment. The different estimates are all in the same "ballpark." 


\section{Bibliography}

American Public Transportation Association. 2013. Public Transportation Ridership Report: Second Quarter 2013. Accessed October 23, 2013.

http://www.apta.com/resources/statistics/Pages/ridershipreport.aspx.

Bailey, L., P. L. Mokhtarian and A. Little. 2008. The Broader Connection between Public Transportation, Energy Conservation and Greenhouse Gas Reduction. Accessed October 23, 2013.

http://www.apta.com/gap/policyresearch/Documents/land_use.pdf.

Bhattacharjee, S. and A. Goetz. 2012. Impact of light rail on traffic congestion in Denver. Journal of Transport Geography 22: 262-270.

Cervero, R. and J. Murakami. 2010. Effects of Built environments on Vehicle Miles Traveled: Evidence from 370 US Urbanized Areas, Environment and Planning A 42: 400-418.

Duranton, G. and M. A. Turner. 2011. The fundamental law of road congestion: evidence from US cities. American Economic Review 101: 2616-2652.

Ewing, R., K. Bartholomew, S. Winkelman, J. Walters, and D. Chen. 2008. Growing Cooler: The Evidence on Urban Development and Climate Change. Washington D.C., Urban Land Institute.

Ewing, R., S. Hamidi, A.C. Nelson, and J. Grace. 2014. Structural Equation Models of VMT Growth in U.S. Urbanized Areas. Urban Studies, published on-line first.

Garrett, T.A. 2004. Light Rail Transit in America: Policy Issues and Prospects for Economic Development. Accessed October 23, 2013.

http://www.stlouisfed.org/community_development/assets/pdf/light_rail.pdf.

Goldstein, D. 2007. Saving Energy, Growing Jobs: How Environmental Protection Promotes Economic Growth, Profitability, Innovation, and Competition. Bay Tree Publishing.

Hyman, G. and L. Mayhew. 2002. Optimizing the benefits of Road User Charging. Transport Policy 9(2002): 189-207.

Lee, S. and M. Senior. 2013. Do light rail services discourage car ownership and use? Evidence from Census data for four English cities. Journal of Transport Geography 29: 11-23.

Litman, T.. 2007. Evaluating Rail Transit Benefits: A Comment. Transport Policy 14(2007): 94-97.

Litman, T., 2012. Rail Transit in America A Comprehensive Evaluation of Benefits. Accessed October 23, 2013. http://www.vtpi.org/railben.pdf.

O’Toole, R. 2008. Does Rail Transit Save Energy or Reduce Greenhouse Gas Emissions? Policy Study No. 614. http://object.cato.org/sites/cato.org/files/pubs/pdf/pa-615.pdf. 
Parry, I. and K. Small. 2009. Should Urban Transit Subsidies be Reduced? American Economic Review 99(3): 700-724.

Schrank, D., B. Eisele and T. Lomax. 2012. TTI's 2012 urban mobility report. Texas A\&M Transportation Institute. Accessed October 23, 2013.

http://d2dt|5nnlpfrOr.cloudfront.net/tti.tamu.edu/documents/mobility-report-2012.pdf.

Senior, M. 2009. Impacts on travel behaviour of Greater Manchester's light rail investment (Metrolink Phase 1): evidence from household surveys and Census data. Journal of transport Geography 17: 187197.

Shadish, W. R., T. D. Cook and D. T. Campbell. 2002. Experimental and Quasi-Experimental Designs for Generalized Causal Inference. Boston, MA, Houghton Mifflin.

Warburton, N. 2007. TRAX ridership numbers pit UTA, critics. Deseret News. Accessed November 4, 2013. http://www.deseretnews.com/article/695195968/TRAX-ridership-numbers-pit-UTA-critics.html.

Winston, C. and A. Langer. 2006. Effect of Government Highway Spending on Road Users' Congestion Costs. Journal of Urban Economics 60(2): 362-382. 


\section{Appendix 1}

\section{Complete list of parcels that experienced changes between 1999 and 2009}

The university's buildings are classified as hospital, university housing, research park, and main campus. The trip generation is calculated as a whole in one parcel for each category.

*: for university housing, the trip rate depends on the type of the housing, such as dorms, apartments and family houses.

**: for the main campus, the trip rate is 1.71 per student, and 8.96 per employee.

\begin{tabular}{|c|c|c|c|c|c|c|c|c|}
\hline \multirow[b]{2}{*}{ Parcel ID } & \multicolumn{4}{|c|}{1999} & \multicolumn{4}{|c|}{2009} \\
\hline & Land use & $\begin{array}{c}\text { Total } \\
\text { sqft }\end{array}$ & $\begin{array}{l}\text { Trip } \\
\text { rate }\end{array}$ & Trips & Land use & $\begin{array}{c}\text { Total } \\
\text { sqft }\end{array}$ & $\begin{array}{l}\text { Trip } \\
\text { rate }\end{array}$ & Trips \\
\hline $9334520142000^{2}$ & public & 3221620 & 16.5 & 53156.73 & public & 4774036 & 16.5 & 78771.56 \\
\hline $16031000042000^{2}$ & public & 1054563 & $*$ & 10236.9 & public & 1845098 & $*$ & 20788.77 \\
\hline $16033000022000^{2}$ & commercial & 1567984 & 8.11 & 12716.35 & commercial & 2090991 & 8.11 & 16957.94 \\
\hline $16042000020000^{2}$ & public & 6147259 & $* *$ & 71592.71 & public & 6197695 & $* *$ & 82170.36 \\
\hline 16051530020000 & residential & 3380 & 9.57 & 19.14 & other & 0 & 0 & 0 \\
\hline 16051530030000 & residential & 2993 & 9.57 & 232.75 & other & 3462 & 0 & 0 \\
\hline 16051530060000 & other & 0 & 0 & 0 & residential & 2082 & 9.57 & 9.57 \\
\hline 16051610010000 & other & 0 & 0 & 0 & residential & 4734 & 19.14 & 19.14 \\
\hline 16051620160000 & other & 0 & 0 & 0 & residential & 2144 & 9.57 & 9.57 \\
\hline 16052010052000 & commercial & 11302 & 11.01 & 124.4 & commercial & 17865 & 11.01 & 196.7 \\
\hline 16052520130000 & other & 0 & 0 & 0 & residential & 3877 & 9.57 & 9.57 \\
\hline 16053010250000 & other & 41914 & 0 & 0 & commercial & 90278 & 42.94 & 3876.5 \\
\hline 16053380010000 & other & 0 & 0 & 0 & residential & 1624 & 5.81 & 5.81 \\
\hline 16053380020000 & other & 0 & 0 & 0 & residential & 1399 & 5.81 & 5.81 \\
\hline 16053380030000 & other & 0 & 0 & 0 & residential & 1399 & 5.81 & 5.81 \\
\hline 16053380040000 & other & 0 & 0 & 0 & residential & 1259 & 5.81 & 5.81 \\
\hline 16053380050000 & other & 0 & 0 & 0 & residential & 1399 & 5.81 & 5.81 \\
\hline 16053380060000 & other & 0 & 0 & 0 & residential & 1399 & 5.81 & 5.81 \\
\hline 16053380070000 & other & 0 & 0 & 0 & residential & 1399 & 5.81 & 5.81 \\
\hline 16053380080000 & other & 0 & 0 & 0 & residential & 1259 & 5.81 & 5.81 \\
\hline 16053380090000 & other & 0 & 0 & 0 & residential & 1399 & 5.81 & 5.81 \\
\hline 16053380100000 & other & 0 & 0 & 0 & residential & 1399 & 5.81 & 5.81 \\
\hline 16053380110000 & other & 0 & 0 & 0 & residential & 1259 & 5.81 & 5.81 \\
\hline 16053380120000 & other & 0 & 0 & 0 & residential & 896 & 5.81 & 5.81 \\
\hline 16053380130000 & other & 0 & 0 & 0 & residential & 896 & 5.81 & 5.81 \\
\hline 16053820130000 & residential & 0 & 0 & 9.57 & residential & 1970 & 9.57 & 9.57 \\
\hline 16053820140000 & residential & 0 & 0 & 0 & residential & 1730 & 9.57 & 9.57 \\
\hline 16053820170000 & other & 0 & 0 & 0 & residential & 1898 & 9.57 & 9.57 \\
\hline
\end{tabular}




\begin{tabular}{|c|c|c|c|c|c|c|c|c|}
\hline 16053820180000 & other & 0 & 0 & 0 & residential & 1730 & 9.57 & 9.57 \\
\hline 16053820190000 & other & 0 & 0 & 0 & residential & 1898 & 9.57 & 9.57 \\
\hline 16054260060000 & residential & 0 & 0 & 0 & residential & 1507 & 9.57 & 9.57 \\
\hline 16054260310000 & other & 0 & 0 & 0 & residential & 3558 & 9.57 & 9.57 \\
\hline 16061040180000 & public & 18343 & 27.92 & 512.13656 & other & 0 & 0 & 0 \\
\hline 16061040210000 & public & 13013 & 27.92 & 363 & other & 0 & 0 & 0 \\
\hline 16061260060000 & public & 19842 & 27.92 & 553 & other & 0 & 0 & 0 \\
\hline 16061270230000 & other & 0 & 0 & 0 & public & 16295 & 9.11 & 148.44 \\
\hline 16061270240000 & public & 8000 & 9.11 & 72.88 & public & 19436 & 9.11 & 177 \\
\hline 16061280080000 & public & 20516 & 27.92 & 572.80672 & other & 0 & 0 & 0 \\
\hline 16061510290000 & commercial & 16263 & 11.01 & 116 & commercial & 160716 & 11.01 & 1769 \\
\hline 16061520780000 & other & 0 & 0 & 0 & commercial & 398580 & 8.92 & 3202.28 \\
\hline 16061560800000 & commercial & 10537 & 11.01 & 116.01237 & commercial & 114326 & 11.01 & 1258.729 \\
\hline 16061820190000 & other & 0 & 0 & 0 & residential & 132748 & 98.85 & 98.85 \\
\hline 16062040250000 & commercial & 0 & 0 & 0 & commercial & 67274 & 3.71 & 860.72 \\
\hline 16062050170000 & public & 164654 & 27.92 & 4597.1397 & public & 133833 & 27.92 & 3736.617 \\
\hline 16061780210000 & commercial & 1763 & 496.12 & 874.7 & other & 0 & 0 & 0 \\
\hline 16062290290000 & other & 0 & 0 & 0 & residential & 1456 & 9.57 & 9.57 \\
\hline 16062290300000 & other & 0 & 0 & 0 & residential & 1304 & 9.57 & 9.57 \\
\hline 16062290310000 & other & 0 & 0 & 0 & residential & 1456 & 9.57 & 9.57 \\
\hline 16062290320000 & other & 0 & 0 & 0 & residential & 1456 & 9.57 & 9.57 \\
\hline 16062290330000 & other & 0 & 0 & 0 & residential & 1223 & 9.57 & 9.57 \\
\hline 16062290340000 & other & 0 & 0 & 0 & residential & 1243 & 9.57 & 9.57 \\
\hline 16062290350000 & other & 0 & 0 & 0 & residential & 1464 & 9.57 & 9.57 \\
\hline 16062290360000 & other & 0 & 0 & 0 & residential & 1304 & 9.57 & 9.57 \\
\hline 16062290370000 & other & 0 & 0 & 0 & residential & 1456 & 9.57 & 9.57 \\
\hline 16062290380000 & other & 0 & 0 & 0 & residential & 1460 & 9.57 & 9.57 \\
\hline 16062290390000 & other & 0 & 0 & 0 & residential & 1212 & 9.57 & 9.57 \\
\hline 16062530500000 & commercial & 1962 & 42.94 & 84.24828 & commercial & 5356 & 42.94 & 229.9866 \\
\hline 16062810020000 & commercial & 49708 & 102.24 & 5082.1459 & commercial & 55252 & 102.24 & 5648.964 \\
\hline 16062830090000 & commercial & 3773 & 50 & 188.65 & other & 0 & 0 & 0 \\
\hline 16063100010000 & other & 0 & 0 & 0 & residential & 1190 & 11.01 & 13.1019 \\
\hline 16063100020000 & other & 0 & 0 & 0 & residential & 863 & 11.01 & 9.50163 \\
\hline 16063100030000 & other & 0 & 0 & 0 & residential & 1012 & 11.01 & 11.14212 \\
\hline 16063100040000 & other & 0 & 0 & 0 & residential & 1519 & 11.01 & 16.72419 \\
\hline 16063100050000 & other & 0 & 0 & 0 & residential & 1263 & 5.81 & 5.81 \\
\hline 16063100060000 & other & 0 & 0 & 0 & residential & 1013 & 5.81 & 5.81 \\
\hline 16063100070000 & other & 0 & 0 & 0 & residential & 1013 & 5.81 & 5.81 \\
\hline 16063100080000 & other & 0 & 0 & 0 & residential & 1557 & 5.81 & 5.81 \\
\hline 16063100090000 & other & 0 & 0 & 0 & residential & 1391 & 5.81 & 5.81 \\
\hline 16063100100000 & other & 0 & 0 & 0 & residential & 1391 & 5.81 & 5.81 \\
\hline
\end{tabular}




\begin{tabular}{|c|c|c|c|c|c|c|c|c|}
\hline 16063100110000 & other & 0 & 0 & 0 & residential & 795 & 5.81 & 5.81 \\
\hline 16063100120000 & other & 0 & 0 & 0 & residential & 1018 & 5.81 & 5.81 \\
\hline 16063100130000 & other & 0 & 0 & 0 & residential & 763 & 5.81 & 5.81 \\
\hline 16063100140000 & other & 0 & 0 & 0 & residential & 1018 & 5.81 & 5.81 \\
\hline 16063100150000 & other & 0 & 0 & 0 & residential & 763 & 5.81 & 5.81 \\
\hline 16063100160000 & other & 0 & 0 & 0 & residential & 582 & 5.81 & 5.81 \\
\hline 16063100170000 & other & 0 & 0 & 0 & residential & 582 & 5.81 & 5.81 \\
\hline 16063100180000 & other & 0 & 0 & 0 & residential & 1018 & 5.81 & 5.81 \\
\hline 16063100190000 & other & 0 & 0 & 0 & residential & 1018 & 5.81 & 5.81 \\
\hline 16063100200000 & other & 0 & 0 & 0 & residential & 1018 & 5.81 & 5.81 \\
\hline 16063100210000 & other & 0 & 0 & 0 & residential & 975 & 5.81 & 5.81 \\
\hline 16063100220000 & other & 0 & 0 & 0 & residential & 1394 & 5.81 & 5.81 \\
\hline 16063100230000 & other & 0 & 0 & 0 & residential & 1018 & 5.81 & 5.81 \\
\hline 16063100240000 & other & 0 & 0 & 0 & residential & 582 & 5.81 & 5.81 \\
\hline 16063100250000 & other & 0 & 0 & 0 & residential & 1018 & 5.81 & 5.81 \\
\hline 16063100260000 & other & 0 & 0 & 0 & residential & 975 & 5.81 & 5.81 \\
\hline 16063100270000 & other & 0 & 0 & 0 & residential & 1018 & 5.81 & 5.81 \\
\hline 16063100280000 & other & 0 & 0 & 0 & residential & 1136 & 5.81 & 5.81 \\
\hline 16063100290000 & other & 0 & 0 & 0 & residential & 1391 & 5.81 & 5.81 \\
\hline 16063100300000 & other & 0 & 0 & 0 & residential & 1391 & 5.81 & 5.81 \\
\hline 16063100310000 & other & 0 & 0 & 0 & residential & 1391 & 5.81 & 5.81 \\
\hline 16063100320000 & other & 0 & 0 & 0 & residential & 795 & 5.81 & 5.81 \\
\hline 16063100330000 & other & 0 & 0 & 0 & residential & 1018 & 5.81 & 5.81 \\
\hline 16063100340000 & other & 0 & 0 & 0 & residential & 763 & 5.81 & 5.81 \\
\hline 16063100350000 & other & 0 & 0 & 0 & residential & 1018 & 5.81 & 5.81 \\
\hline 16063100360000 & other & 0 & 0 & 0 & residential & 763 & 5.81 & 5.81 \\
\hline 16063100370000 & other & 0 & 0 & 0 & residential & 582 & 5.81 & 5.81 \\
\hline 16063100380000 & other & 0 & 0 & 0 & residential & 582 & 5.81 & 5.81 \\
\hline 16063100390000 & other & 0 & 0 & 0 & residential & 1018 & 5.81 & 5.81 \\
\hline 16063100400000 & other & 0 & 0 & 0 & residential & 1018 & 5.81 & 5.81 \\
\hline 16063100410000 & other & 0 & 0 & 0 & residential & 1018 & 5.81 & 5.81 \\
\hline 16063100420000 & other & 0 & 0 & 0 & residential & 975 & 5.81 & 5.81 \\
\hline 16063100430000 & other & 0 & 0 & 0 & residential & 693 & 5.81 & 5.81 \\
\hline 16063100440000 & other & 0 & 0 & 0 & residential & 1394 & 5.81 & 5.81 \\
\hline 16063100450000 & other & 0 & 0 & 0 & residential & 774 & 5.81 & 5.81 \\
\hline 16063100460000 & other & 0 & 0 & 0 & residential & 1018 & 5.81 & 5.81 \\
\hline 16063100470000 & other & 0 & 0 & 0 & residential & 582 & 5.81 & 5.81 \\
\hline 16063100480000 & other & 0 & 0 & 0 & residential & 1018 & 5.81 & 5.81 \\
\hline 16063100490000 & other & 0 & 0 & 0 & residential & 975 & 5.81 & 5.81 \\
\hline 16063100500000 & other & 0 & 0 & 0 & residential & 1018 & 5.81 & 5.81 \\
\hline 16063100510000 & other & 0 & 0 & 0 & residential & 1136 & 5.81 & 5.81 \\
\hline
\end{tabular}




\begin{tabular}{|c|c|c|c|c|c|c|c|c|}
\hline 16063100520000 & other & 0 & 0 & 0 & residential & 1391 & 5.81 & 5.81 \\
\hline 16063100530000 & other & 0 & 0 & 0 & residential & 1391 & 5.81 & 5.81 \\
\hline 16063100540000 & other & 0 & 0 & 0 & residential & 1391 & 5.81 & 5.81 \\
\hline 16063100550000 & other & 0 & 0 & 0 & residential & 795 & 5.81 & 5.81 \\
\hline 16063100560000 & other & 0 & 0 & 0 & residential & 1018 & 5.81 & 5.81 \\
\hline 16063100570000 & other & 0 & 0 & 0 & residential & 763 & 5.81 & 5.81 \\
\hline 16063100580000 & other & 0 & 0 & 0 & residential & 1018 & 5.81 & 5.81 \\
\hline 16063100590000 & other & 0 & 0 & 0 & residential & 763 & 5.81 & 5.81 \\
\hline 16063100600000 & other & 0 & 0 & 0 & residential & 582 & 5.81 & 5.81 \\
\hline 16063100610000 & other & 0 & 0 & 0 & residential & 582 & 5.81 & 5.81 \\
\hline 16063100620000 & other & 0 & 0 & 0 & residential & 1018 & 5.81 & 5.81 \\
\hline 16063100630000 & other & 0 & 0 & 0 & residential & 1018 & 5.81 & 5.81 \\
\hline 16063100640000 & other & 0 & 0 & 0 & residential & 1018 & 5.81 & 5.81 \\
\hline 16063100650000 & other & 0 & 0 & 0 & residential & 975 & 5.81 & 5.81 \\
\hline 16063100660000 & other & 0 & 0 & 0 & residential & 693 & 5.81 & 5.81 \\
\hline 16063100670000 & other & 0 & 0 & 0 & residential & 514 & 5.81 & 5.81 \\
\hline 16063100680000 & other & 0 & 0 & 0 & residential & 774 & 5.81 & 5.81 \\
\hline 16063100690000 & other & 0 & 0 & 0 & residential & 1064 & 5.81 & 5.81 \\
\hline 16063100700000 & other & 0 & 0 & 0 & residential & 582 & 5.81 & 5.81 \\
\hline 16063100710000 & other & 0 & 0 & 0 & residential & 1018 & 5.81 & 5.81 \\
\hline 16063100720000 & other & 0 & 0 & 0 & residential & 975 & 5.81 & 5.81 \\
\hline 16063100730000 & other & 0 & 0 & 0 & residential & 1018 & 5.81 & 5.81 \\
\hline 16063100740000 & other & 0 & 0 & 0 & residential & 1147 & 5.81 & 5.81 \\
\hline 16063100750000 & other & 0 & 0 & 0 & residential & 1391 & 5.81 & 5.81 \\
\hline 16063100760000 & other & 0 & 0 & 0 & residential & 1391 & 5.81 & 5.81 \\
\hline 16063100770000 & other & 0 & 0 & 0 & residential & 1391 & 5.81 & 5.81 \\
\hline 16063100780000 & other & 0 & 0 & 0 & residential & 795 & 5.81 & 5.81 \\
\hline 16063100790000 & other & 0 & 0 & 0 & residential & 1018 & 5.81 & 5.81 \\
\hline 16063100800000 & other & 0 & 0 & 0 & residential & 633 & 5.81 & 5.81 \\
\hline 16063100810000 & other & 0 & 0 & 0 & residential & 1066 & 5.81 & 5.81 \\
\hline 16063100820000 & other & 0 & 0 & 0 & residential & 763 & 5.81 & 5.81 \\
\hline 16063100830000 & other & 0 & 0 & 0 & residential & 582 & 5.81 & 5.81 \\
\hline 16063100840000 & other & 0 & 0 & 0 & residential & 582 & 5.81 & 5.81 \\
\hline 16063100850000 & other & 0 & 0 & 0 & residential & 1018 & 5.81 & 5.81 \\
\hline 16063100860000 & other & 0 & 0 & 0 & residential & 1018 & 5.81 & 5.81 \\
\hline 16063100870000 & other & 0 & 0 & 0 & residential & 1018 & 5.81 & 5.81 \\
\hline 16063100880000 & other & 0 & 0 & 0 & residential & 975 & 5.81 & 5.81 \\
\hline 16063100890000 & other & 0 & 0 & 0 & residential & 693 & 5.81 & 5.81 \\
\hline 16063100900000 & other & 0 & 0 & 0 & residential & 1394 & 5.81 & 5.81 \\
\hline 16063100910000 & other & 0 & 0 & 0 & residential & 774 & 5.81 & 5.81 \\
\hline 16063100920000 & other & 0 & 0 & 0 & residential & 1018 & 5.81 & 5.81 \\
\hline
\end{tabular}




\begin{tabular}{|c|c|c|c|c|c|c|c|c|}
\hline 16063100930000 & other & 0 & 0 & 0 & residential & 582 & 5.81 & 5.81 \\
\hline 16063100940000 & other & 0 & 0 & 0 & residential & 1018 & 5.81 & 5.81 \\
\hline 16063100950000 & other & 0 & 0 & 0 & residential & 975 & 5.81 & 5.81 \\
\hline 16063100960000 & other & 0 & 0 & 0 & residential & 1018 & 5.81 & 5.81 \\
\hline 16063100970000 & other & 0 & 0 & 0 & residential & 1147 & 5.81 & 5.81 \\
\hline 16063100980000 & other & 0 & 0 & 0 & residential & 1391 & 5.81 & 5.81 \\
\hline 16063100990000 & other & 0 & 0 & 0 & residential & 1391 & 5.81 & 5.81 \\
\hline 16063101000000 & other & 0 & 0 & 0 & residential & 1403 & 5.81 & 5.81 \\
\hline 16063101010000 & other & 0 & 0 & 0 & residential & 795 & 5.81 & 5.81 \\
\hline 16063101020000 & other & 0 & 0 & 0 & residential & 1018 & 5.81 & 5.81 \\
\hline 16063101030000 & other & 0 & 0 & 0 & residential & 763 & 5.81 & 5.81 \\
\hline 16063101040000 & other & 0 & 0 & 0 & residential & 1066 & 5.81 & 5.81 \\
\hline 16063101050000 & other & 0 & 0 & 0 & residential & 763 & 5.81 & 5.81 \\
\hline 16063101060000 & other & 0 & 0 & 0 & residential & 582 & 5.81 & 5.81 \\
\hline 16063101070000 & other & 0 & 0 & 0 & residential & 647 & 5.81 & 5.81 \\
\hline 16063101080000 & other & 0 & 0 & 0 & residential & 1018 & 5.81 & 5.81 \\
\hline 16063101090000 & other & 0 & 0 & 0 & residential & 1018 & 5.81 & 5.81 \\
\hline 16063101100000 & other & 0 & 0 & 0 & residential & 1018 & 5.81 & 5.81 \\
\hline 16063101110000 & other & 0 & 0 & 0 & residential & 975 & 5.81 & 5.81 \\
\hline 16063101120000 & other & 0 & 0 & 0 & residential & 693 & 5.81 & 5.81 \\
\hline 16063101130000 & other & 0 & 0 & 0 & residential & 1394 & 5.81 & 5.81 \\
\hline 16063101140000 & other & 0 & 0 & 0 & residential & 774 & 5.81 & 5.81 \\
\hline 16063101150000 & other & 0 & 0 & 0 & residential & 1054 & 5.81 & 5.81 \\
\hline 16063101160000 & other & 0 & 0 & 0 & residential & 582 & 5.81 & 5.81 \\
\hline 16063101170000 & other & 0 & 0 & 0 & residential & 1054 & 5.81 & 5.81 \\
\hline 16063101180000 & other & 0 & 0 & 0 & residential & 975 & 5.81 & 5.81 \\
\hline 16063101190000 & other & 0 & 0 & 0 & residential & 1018 & 5.81 & 5.81 \\
\hline 16063101200000 & other & 0 & 0 & 0 & residential & 1147 & 5.81 & 5.81 \\
\hline 16063101210000 & other & 0 & 0 & 0 & residential & 1403 & 5.81 & 5.81 \\
\hline 16063300190000 & public & 135978 & 27.92 & 3796.5058 & public & 327159 & 27.92 & 9134.279 \\
\hline 16063310130000 & public & 50276 & 27.92 & 1403.7059 & public & 45123 & 27.92 & 1259.834 \\
\hline 16063510230000 & commercial & 0 & 0 & 0 & commercial & 1685831 & 8.92 & 6913 \\
\hline 16063760220000 & commercial & 18724 & 33.34 & 624.25816 & commercial & 124854 & 33.34 & 4162.632 \\
\hline 16063770150000 & residential & 5173 & 98.85 & 511.35105 & residential & 76694 & 98.85 & 7581.202 \\
\hline 16063790010000 & commercial & 407 & 9.57 & 9.57 & commercial & 0 & 0 & 0 \\
\hline 16064020030000 & commercial & 3038 & 11.01 & 33.44838 & other & 0 & 0 & 0 \\
\hline 16064070410000 & commercial & 1385 & 156.48 & 216.7248 & commercial & 12175 & 156.48 & 1905.144 \\
\hline 16064260090000 & residential & 18351 & 9.57 & 78.56 & residential & 324605 & 4.2 & 1058.4 \\
\hline 16064270380000 & residential & 12555 & 9.57 & 162.41 & other & 0 & 0 & 0 \\
\hline 16064270390000 & commercial & 12873 & 90.06 & 1159.3424 & commercial & 14503 & 90.06 & 1306.14 \\
\hline 16064340090000 & commercial & 4336 & 50 & 216.8 & other & 0 & 0 & 0 \\
\hline
\end{tabular}




\begin{tabular}{|c|c|c|c|c|c|c|c|c|}
\hline 16064660010000 & other & 0 & 0 & 0 & residential & 1034 & 5.81 & 5.81 \\
\hline 16064660020000 & other & 0 & 0 & 0 & residential & 1034 & 5.81 & 5.81 \\
\hline 16064660030000 & other & 0 & 0 & 0 & residential & 1034 & 5.81 & 5.81 \\
\hline 16064660040000 & other & 0 & 0 & 0 & residential & 1034 & 5.81 & 5.81 \\
\hline 16064660050000 & other & 0 & 0 & 0 & residential & 1034 & 5.81 & 5.81 \\
\hline 16064660060000 & other & 0 & 0 & 0 & residential & 1034 & 5.81 & 5.81 \\
\hline 16064660070000 & other & 0 & 0 & 0 & residential & 1034 & 5.81 & 5.81 \\
\hline 16064660080000 & other & 0 & 0 & 0 & residential & 1034 & 5.81 & 5.81 \\
\hline 16064660090000 & other & 0 & 0 & 0 & residential & 1034 & 5.81 & 5.81 \\
\hline 16064660100000 & other & 0 & 0 & 0 & residential & 1034 & 5.81 & 5.81 \\
\hline 16064660110000 & other & 0 & 0 & 0 & residential & 1034 & 5.81 & 5.81 \\
\hline 16064660120000 & other & 0 & 0 & 0 & residential & 1034 & 5.81 & 5.81 \\
\hline 16064660130000 & other & 0 & 0 & 0 & residential & 1034 & 5.81 & 5.81 \\
\hline 16064660140000 & other & 0 & 0 & 0 & residential & 1034 & 5.81 & 5.81 \\
\hline 16064660150000 & other & 0 & 0 & 0 & residential & 1034 & 5.81 & 5.81 \\
\hline 16064660160000 & other & 0 & 0 & 0 & residential & 1034 & 5.81 & 5.81 \\
\hline 16064660170000 & other & 0 & 0 & 0 & residential & 1034 & 5.81 & 5.81 \\
\hline 16064660180000 & other & 0 & 0 & 0 & residential & 1034 & 5.81 & 5.81 \\
\hline 16064660190000 & other & 0 & 0 & 0 & residential & 1034 & 5.81 & 5.81 \\
\hline 16064660200000 & other & 0 & 0 & 0 & residential & 1034 & 5.81 & 5.81 \\
\hline 16064660210000 & other & 0 & 0 & 0 & residential & 1034 & 5.81 & 5.81 \\
\hline 16064660220000 & other & 0 & 0 & 0 & residential & 1034 & 5.81 & 5.81 \\
\hline 16064660230000 & other & 0 & 0 & 0 & residential & 1034 & 5.81 & 5.81 \\
\hline 16064660240000 & other & 0 & 0 & 0 & residential & 1034 & 5.81 & 5.81 \\
\hline 16064660250000 & other & 0 & 0 & 0 & residential & 1034 & 5.81 & 5.81 \\
\hline 16064660260000 & other & 0 & 0 & 0 & residential & 1034 & 5.81 & 5.81 \\
\hline 16064660270000 & other & 0 & 0 & 0 & residential & 1034 & 5.81 & 5.81 \\
\hline 16064660280000 & other & 0 & 0 & 0 & residential & 1034 & 5.81 & 5.81 \\
\hline 16064660290000 & other & 0 & 0 & 0 & residential & 1034 & 5.81 & 5.81 \\
\hline 16064660300000 & other & 0 & 0 & 0 & residential & 1034 & 5.81 & 5.81 \\
\hline 16064660310000 & other & 0 & 0 & 0 & residential & 1034 & 5.81 & 5.81 \\
\hline 16064660320000 & other & 0 & 0 & 0 & residential & 1034 & 5.81 & 5.81 \\
\hline 16064660330000 & other & 0 & 0 & 0 & residential & 1034 & 5.81 & 5.81 \\
\hline 16064660340000 & other & 0 & 0 & 0 & residential & 1034 & 5.81 & 5.81 \\
\hline 16064660350000 & other & 0 & 0 & 0 & residential & 1034 & 5.81 & 5.81 \\
\hline 16064660360000 & other & 0 & 0 & 0 & residential & 1034 & 5.81 & 5.81 \\
\hline 16064660370000 & other & 0 & 0 & 0 & residential & 1034 & 5.81 & 5.81 \\
\hline 16064660380000 & other & 0 & 0 & 0 & residential & 1034 & 5.81 & 5.81 \\
\hline 16064660390000 & other & 0 & 0 & 0 & residential & 1034 & 5.81 & 5.81 \\
\hline 16064660400000 & other & 0 & 0 & 0 & residential & 1034 & 5.81 & 5.81 \\
\hline 16064660410000 & other & 0 & 0 & 0 & residential & 1034 & 5.81 & 5.81 \\
\hline
\end{tabular}




\begin{tabular}{|c|c|c|c|c|c|c|c|c|}
\hline 16064660420000 & other & 0 & 0 & 0 & residential & 1034 & 5.81 & 5.81 \\
\hline 16064660430000 & other & 0 & 0 & 0 & residential & 1034 & 5.81 & 5.81 \\
\hline 16064660440000 & other & 3204 & 9.57 & 9.57 & residential & 0 & 0 & 0 \\
\hline 16064770270000 & commercial & 659 & 11.01 & 7.25559 & commercial & 1662 & 11.01 & 18.29862 \\
\hline 16071030190000 & commercial & 3742 & 89.95 & 336.5929 & commercial & 4837 & 89.95 & 435.0882 \\
\hline 16071040070000 & commercial & 3706 & 156.48 & 579.91488 & commercial & 26027 & 156.48 & 4072.705 \\
\hline 16071270120000 & other & 0 & 0 & 0 & public & 3053 & 27.92 & 85.23976 \\
\hline 16071270130000 & other & 0 & 0 & 0 & public & 752 & 27.92 & 20.99584 \\
\hline 16071270210000 & other & 0 & 0 & 0 & public & 1855 & 27.92 & 51.7916 \\
\hline 16071270220000 & other & 0 & 0 & 0 & public & 1446 & 27.92 & 40.37232 \\
\hline 16071270230000 & other & 0 & 0 & 0 & public & 1822 & 27.92 & 50.87024 \\
\hline 16071270240000 & other & 0 & 0 & 0 & public & 2424 & 27.92 & 67.67808 \\
\hline 16071270250000 & other & 0 & 0 & 0 & public & 1050 & 27.92 & 29.316 \\
\hline 16071290450000 & other & 0 & 0 & 0 & residential & 1256 & 9.57 & 9.57 \\
\hline 16071290460000 & other & 0 & 0 & 0 & residential & 1242 & 9.57 & 9.57 \\
\hline 16071290470000 & other & 0 & 0 & 0 & residential & 1668 & 9.57 & 9.57 \\
\hline 16071290480000 & other & 0 & 0 & 0 & residential & 1668 & 9.57 & 9.57 \\
\hline 16071290490000 & other & 0 & 0 & 0 & residential & 1242 & 9.57 & 9.57 \\
\hline 16071290500000 & other & 0 & 0 & 0 & residential & 1242 & 9.57 & 9.57 \\
\hline 16071290510000 & other & 0 & 0 & 0 & residential & 1242 & 9.57 & 9.57 \\
\hline 16071290520000 & other & 0 & 0 & 0 & residential & 1668 & 9.57 & 9.57 \\
\hline 16071290530000 & other & 0 & 0 & 0 & residential & 1668 & 9.57 & 9.57 \\
\hline 16072030100000 & other & 1708 & 0 & 0 & residential & 1720 & 9.57 & 9.57 \\
\hline 16081090010000 & other & 0 & 0 & 0 & residential & 1084 & 5.81 & 5.81 \\
\hline 16081090020000 & other & 0 & 0 & 0 & residential & 1084 & 5.81 & 5.81 \\
\hline 16081090030000 & other & 0 & 0 & 0 & residential & 1084 & 5.81 & 5.81 \\
\hline 16081090040000 & other & 0 & 0 & 0 & residential & 1084 & 5.81 & 5.81 \\
\hline 16081260280000 & residential & 0 & 0 & 0 & residential & 4793 & 23.275 & 23.275 \\
\hline 16081340010000 & residential & 0 & 0 & 0 & residential & 2280 & 9.57 & 9.57 \\
\hline 16081340020000 & residential & 0 & 0 & 0 & residential & 2280 & 9.57 & 9.57 \\
\hline 16081340030000 & residential & 0 & 0 & 0 & residential & 2280 & 9.57 & 9.57 \\
\hline 16081340040000 & residential & 0 & 0 & 0 & residential & 2280 & 9.57 & 9.57 \\
\hline 16081340050000 & residential & 0 & 0 & 0 & residential & 2280 & 9.57 & 9.57 \\
\hline 16081340060000 & residential & 0 & 0 & 0 & residential & 2280 & 9.57 & 9.57 \\
\hline 16081340070000 & residential & 5803 & 9.57 & 19.14 & residential & 0 & 0 & 0 \\
\hline 16091260120000 & public & 0 & 0 & 0 & public & 73877 & 10.02 & 740.3 \\
\hline
\end{tabular}





\section{NITC Marova mstruve for TRANSPORTATION and COMMUNITIES}

P.O. Box 751

Portland, OR 97207

NITC is dedicated to

stimulating and conducting collaborative multi-disciplinary research on multi-modal surface transportation issues, educating a diverse array of current practitioners and future leaders in the transportation field, and encouraging implementation of relevant research results. 